\title{
A distributional approach to functional Danish subclause classification
}

Mortensen, Sune Sønderberg

Published in:

Acta Linguistica Hafniensia: International Journal of Linguistics

DOI:

$10.1080 / 03740463.2012 .709742$

Publication date:

2011

Document version

Early version, also known as pre-print

Citation for published version (APA):

Mortensen, S. S. (2011). A distributional approach to functional Danish subclause classification. Acta Linguistica Hafniensia: International Journal of Linguistics , 43(2), 127-175. https://doi.org/10.1080/03740463.2012.709742 


\title{
A distributional approach to functional Danish subclause classification
}

\author{
Sune Sønderberg Mortensen* \\ Department of Scandinavian Studies and Linguistics, University of Copenhagen \\ This paper proposes a general structural-functional classification of Danish \\ subclauses, based on their distributional properties. It is argued that \\ traditional divisions into, for example, nominal/complement, attributive/ \\ relative and adverbial subclauses are inadequate on their own, because they \\ only account for the syntactic functions of the clauses in realized discourse. \\ Attempts at classifying subclauses at an abstract level tend to rely on the idea \\ that each subclause form has a "default" syntactic function, but this paper \\ argues that Danish subclauses may be dealt with more accurately by \\ acknowledging and indeed exploiting their multifunctionality. Thus, a \\ division into five distinct subclause classes is proposed, grouping the clauses \\ according to their abstract potentials for occurring in specific syntactic \\ functions and positions in the superordinate clause. The main inventory of \\ Danish subclauses are classified on this basis, allowing for predictability \\ between individual subclause types and their functional potentials.
}

Keywords: Subordinate clauses; syntax; grammar; classification; Danish

\section{Introduction}

Subordinate clauses, also referred to as for example embedded, dependent or constituent clauses, form part of the stock inventory of most general grammar accounts (e.g. Diderichsen 1946; Dik 1997b; Faarlund, Lie and Vannebo 1997; Givón 1984; Halliday 1994; Hansen and Heltoft 2011; Huddleston and Pullum 2002; Jespersen 1927; Mikkelsen 1911; Quirk et al. 1985; Teleman, Hellberg and Andersson 1999; Van Valin and La Polla 1997; Wiwel 1901), and are frequently treated on more or less individual terms as well (e.g. Andersson 1975; Cristofaro 2003; E. Hansen 1998; Hengeveld 1996; 1998; Huddleston and Pullum 2004; A. Jensen 2003; T.J. Jensen 2011; Jespersen 1939-40; Laury and Suzuki 2011; Lehmann 1988; Mortensen 2006; 2011; Smessaert et al. 2005; Verstraete 2007). Although subclauses, as they are referred to here, are usually treated on the basis of general subclause typologies, the actual criteria for these typologies have, at least in the Danish grammar tradition, received little attention. Generally, Danish grammars classify subclauses in accordance with most traditional frameworks, i.e. on the basis of their realized syntactic functions.

However, in this paper I argue that the traditional approach tends to disregard the basic distinction of function and form, either leaving the latter unaccounted for

\footnotetext{
*Email: sunsm@hum.ku.dk
} 
or conflating the two levels of description, with the result that the classification of Danish subclauses in fact provides no or little information about the subclauses in their own respect. Thus, it is my general argument that the analytical level of form (or material in my terminology; cf. section 2.3.) needs to be applied more systematically and accurately, in order to account for the complex relations between the expressions and functions of Danish subclauses. In particular, I argue that exploring the syntactic distribution of subclause material, i.e. the syntactic potential of each subclause type rather than just its specific realization (cf. section 3.1.), provides a sound basis for classification at the level of material. I illustrate this by detailing a five-part Danish subclause classification at material level, into nuclear clauses, semi-nuclear clauses, non-nuclear clauses, attributional clauses and appendix clauses. Each class is defined by its own set of distributional properties and characterized in terms of general semantic features.

\section{Theoretical preliminaries}

\subsection{What is a (Danish) subclause?}

While grammatical treatments of subclauses are fraught with terminological difficulties and disagreements (cf. for example Butler 2003; Cristofaro 2003; Jendraschek 2007; A. Jensen 2003), the fact that I employ the term "subclause" rather than, say, "embedded" or "dependent" clause should not be taken to imply that I defend a particular theoretical stance. The choice is simply motivated by the fact that the term sub(ordinate)clause is in many frameworks seen as a common denominator for a range of more or less related clause phenomena (e.g. Cristofaro 2003; Jendraschek 2007; Quirk et al. 1985). Thus, I adopt the general notion of subclause widely used in traditional and modern Danish grammar (e.g. A. Hansen 1967; E. Hansen 1977; Hansen and Heltoft 2011; Mikkelsen 1911; Togeby 2003), ${ }^{1}$ and define subclauses simply as clauses that are constituents of other clauses - referred to as superordinate clauses - or of constituents of these for example:

(1) De troede [at Jorden var flad] ${ }^{2}$

'They believed [that the Earth was flat]'

(2) Jeg så en mand [som lфb rundt i pyjamas]

'I saw a man [who was running around in his pyjamas]'

\footnotetext{
${ }^{1}$ In recent Danish grammar, subclauses are usually referred to as ledsatninger or, alternatively, bisatninger. The former translates as 'constituent clauses' and the latter roughly as 'secondary clauses'.

${ }^{2}$ Throughout this paper, the relevant subclause in each example is framed by square brackets. Examples with no reference are derived, repeated or constructed, cf. section 3.2. Examples considered impossible in Danish are preceded by asterisks, while examples considered problematic, odd or indeterminable in the given contexts are preceded by two question marks. Each Danish example is followed by an approximate English translation, but only the Danish versions are accounted for.
} 


\section{(3) Jeg så ham [da jeg kørte hjem fra arbejde]}

'I saw him [when I was driving home from work]'

This definition, albeit fairly unspecific, provides a sufficient basic framework for the analyses to follow, since my focus is not on the criteria for defining subclauses per se, but rather on the differences between them. Moreover, it should be noted that I follow the Danish tradition of reserving the term "subclause" for finite clause structures, unlike other traditions where subclauses may include both finite and non-finite structures (see also Lehmann 1988: 219, note 1). In other words, I deal only with subclauses featuring one or more finite verbs, i.e. verbs in the present or past tense. While including, for example, Danish infinitival structures would be an interesting extension, the finiteness criterion does provide a well-placed limitation, so I see no reason to counter the Danish tradition in this respect.

\subsection{Existing approaches to subclause classification}

As noted, Danish subclauses are traditionally - although terminology and level of detail vary - classified on the basis of syntactic principles parallel to those of most other functionally oriented grammar frameworks (cf. for example BeckerChristensen 2010; Cristofaro 2003; Dik 1997b; Faarlund, Lie and Vannebo 1997; Givón 1984; Hansen and Heltoft 2011; Hengeveld and Mackenzie 2008; Jespersen 1927, 1939-40; Quirk et al. 1985; Teleman, Hellberg and Andersson 1999; Togeby 2003; Van Valin and La Polla 1997). Thus, in (1) above, the subclause functions as a direct object in the superordinate clause and might thus be classified as a nominal or complement clause. In (2), the subclause functions as a postmodifier to a constituent (direct object) of the superordinate clause and might therefore be classified as a relative clause or, in more general terms, an attributive clause (a definition of which will follow in section 3.4.4.). In (3), the subclause functions as an adverbial and might thus be classified as an adverbial clause.

This sort of functional classification is an indispensible analytical tool, in that subclauses do occur in (at least) the three kinds of functions mentioned. However, the approach suffers from the intrinsic shortcoming that it only accounts for realized constructions of subclauses in discourse, and not for subclauses based on their inherent properties (as also discussed in Mortensen 2011). Some languagespecific grammar accounts seek to "complete" the description by mapping "default functions", as it were, to particular kinds of subclauses, i.e. detailing which specific subclause types may typically or canonically occur in which functions, for example:

The nominal subclauses feature the conjunctions at ['that'], om ['whether'] or (a phrase including) an $h v$-['wh'-]word. The adverbial ones are introduced by a large, yet limited range of conjunctions: hvis ['if'], fordi ['because'], mens ['while'], selvom ['although'] etc. And the adjectival [i.e. attributive] subclauses are introduced by a relative conjunctional, i.e. som ['which'/'that'/'who(m)'] or occur without explicit conjunctional, or thirdly: they are introduced by a pronominal $h v$-['wh'-]form. (Hansen and Heltoft 2011: 1480; my translation) 
Still, as is frequently recognized, for example by Hansen and Heltoft themselves (2011: 1480), such generalizations, although perhaps handy for teaching purposes, are necessarily inaccurate, due to the multifunctionality and polysemy of the subclauses. For example, $d a$-clauses ('when'-clauses), usually treated as adverbial clauses, may also function as, for example, direct objects and thus be nominal clauses (see also Hansen and Heltoft 2011: 38), or as postmodifiers, making them attributive clauses:

(4) Jeg så hendes ansigt [da hun gik forbi]

Adverbial clause

'I saw her face [when she walked by]'

(5) Jeg så [da hun gik forbi]

Direct object: nominal clause

'I saw [when she walked by]'

(6) I det øjeblik [da hun gik forbi], så jeg hendes ansigt Postmodifier: attributive clause 'The moment [when she walked by], I saw her face'

The limited descriptive power of the traditional classification system is criticized by Huddleston and Pullum (2002, 2004), whose solution is to propose a model for classifying (English) subclauses on their own terms. However, they take certain theoretical stances that I regard essentially problematic. One is the explicit rejection of the traditional functional classification altogether (e.g. Huddleston and Pullum 2002: 19), which disregards the complementary nature of the levels of material and function (to be discussed in section 2.3.). They also reject the traditional idea of conjunctions, thus regarding subclauses normally analysed as adverbial as mere "content clauses" governed by prepositions (e.g. Huddleston and Pullum 2002: 1011). This reductionist approach leads, among other things, to the vast majority of subclauses being absorbed by just one class, which arguably undermines the whole idea of classification.

A fine-grained classification of Dutch subordinators/subclauses proposed in Smessaert et al. (2005) explores distributional parameters including pronominal substitution, clefting and fronting possibilities, rendering a hierarchy of "endotactic", "epitactic" and "exotactic" subordinators (all further subclassified). Smessaert et al.'s detailed analytical framework documents a multitude of constructional differences, and while I find Huddleston and Pullum's classification too general and simplistic, Smessaert et al.'s classification on the other hand provides fairly limited levels of generalization, arriving at, for example, five different readings of voraleer ("before").

Finally, a special Danish tradition of classifying subclauses into "explicative', "implicative" and "free" subclauses (Diderichsen 1946; E. Hansen 1998; Hansen and Heltoft 2011; A. Jensen 2003) would, at a glance, appear relevant, as it has been claimed to account for the "essence" of the subclauses as a supplement to their syntactic functions, i.e. their "accidence" (E. Hansen 1998: 20). However, as discussed in Mortensen (2011), this approach arguably amounts to yet another, less consistent, variant of the traditional syntactic approach. 


\subsection{Material vs. function - expression vs. content}

In more general terms, traditional approaches to subclause classification may be said to downplay, in different ways, the distinction of form and function. As I find this distinction central not least in the context of subclause classification, I will briefly outline how I understand and employ it, in contrast to that of expression and content, and why I follow the Danish tradition of using the term material rather than form. The traditional dichotomy of form and function is explained by, for example, Quirk et al. (1985: 48):

We may classify a unit either on the basis of its FORM ( $\mathrm{eg}$ its internal structure, as a noun phrase, or as a verb phrase), or on the basis of its FUNCTION ( $e g$ as a subject or an object of a clause). By function is meant a unit's "privilege of occurrence"... in the unit of which it is a constituent... The advantage of distinguishing functional from formal categories is that generalizations of two kinds can be made: those about a unit's status as a constituent of a higher unit, and those about its internal structure in terms of smaller or lower units.

Thus, any kind of grammatical unit, whether for example a word, a phrase or a clause, etc., may be characterized both in terms of form and function - from a functionalist perspective, the two levels are indeed not only an "advantage", but also complementary to each other, in that linguistic forms exist by virtue of functioning, and functions are inevitably achieved by forms (see also Harder 1996a).

The form/function distinction is not to be conflated with the distinction between expression and content, as employed within sign-based grammar frameworks such as Danish Functional Linguistics (cf. Engberg-Pedersen et al. 1996; 2005; Hansen and Heltoft 2011; Jakobsen 1996), since both expression and content (roughly, semantics) are part of any grammatical unit, whether regarded at the level of form or at the level of function. For instance, the word books as a form carries certain expression features (e.g. the expression of the lexeme itself as well as the $-s$ inflection) and certain content features (e.g. the sense and reference of the lexeme plus the plural meaning of $-s$ ), as does its function in a superordinate clause, for example that of a subject, carrying the general expression and content features associated with subjects (the particulars of which are less relevant in this context).

Probably to avoid confusing "form" with "expression", parts of the Danish grammar tradition tend to opt for the term material instead of form (e.g. Diderichsen 1957[1946]: 166; Hansen and Heltoft 2011: 269), a preference I share since the latter might wrongly associate specifically to the expression side of the grammatical unit in question at the expense of its content side. When referring to subclause material, then, I refer to the internal make-up - both expressionwise and contentwise - of subclauses, primarily identified by the conjunctions introducing them, but also, as will be discussed in section 9.1., partially by the internal word order of the subclauses. 


\section{Classification parameters}

\subsection{Distributional analysis}

As stated in the title, I will employ a distributional approach to classifying subclauses. This is not to imply that other accounts of subclauses are not based on distributional analysis. Rather, I want to argue that taking the distributional analysis of Danish subclauses a bit further - and more seriously - reveals new information about them and gives rise to meaningful classification criteria. By "distributional” analysis, I refer to the general principle of determining the "set of contexts within sentences in which a unit or class of units can appear" (Matthews 2007, online: "distribution"). The verb "can" is crucial here, as I am concerned with possible syntactic functions and topological positions in which classes of Danish subclauses can occur, rather than for example their actual frequency or default occurrences in restricted contexts or corpora (cf. for example Diderichsen 1958; Hansen and Heltoft 2011).

Since not all distributional properties are necessarily (equally) relevant for classification purposes, I concentrate on those distributional properties that reflect shared content features, in order to establish, as far as possible, semantically homogeneous subclause classes.

\subsection{Data sources}

My general aim is to set up classification criteria for all possible subclauses in modern standard Danish, both spoken and written. ${ }^{3}$ More specifically, I will apply the criteria to a representative range of Danish subclauses. Both tasks are based on extensive analyses of authentic subclause examples found in: (a) the LANCHART corpus (sociolinguistic interviews, spoken; see www.lanchart.hum.ku.dk), (b) the BySoc corpus (sociolinguistic interviews, spoken; see bysoc.dyndns.org), (c) Korpus DK (various genres, written; see ordnet.dk/korpusdk), as well as (d) various internet sites. Only examples from BySoc, Korpus DK and internet sites are presented in this paper. In addition, authentic examples are in many cases juxtaposed with derived ones (marked with the same number followed by one or more primes, for example (1')) in order to highlight specific analytical points. Examples in the present introductory sections are constructed ones, illustrating points I consider uncontroversial yet more easily understood through simple, stylized examples. ${ }^{4}$

\subsection{Subclause types, variants and classes}

Most Danish subclauses are introduced by a conjunctional, also known as 'subordinator', i.e. an element connecting the subclause to its superordinate clause, often realized by conjunctions, but also by, for example, $h v$-('wh'-) pronouns and

\footnotetext{
${ }^{3}$ Certain special idiomatic subclause constructions are disregarded as they are considered marginal, just as narrow regional variation and archaic constructions are generally left unaccounted for.

${ }^{4}$ In many examples of spoken language, some transcription symbols as well as other interlocutors' speech are removed.
} 
conjunctional phrases (Hansen and Heltoft 2011: 283). When referring to clause types, I identify them by their conjunctionals, meaning for example that any selvomclause ('although'-clause) is representative of the selvom-clause type, regardless of what the rest of the clause structure looks like. Moreover, due to polysemy, several clause types may be said to come in two or more subclause variants. As I will explain in section 3.5., the general criterion for distinguishing such variants from each other is based on their properties of being either focusable or non-focusable.

Two clause types stand out by being able to occur in most contexts without an explicit conjunction: at-/Ø-clauses ('that'-/Ø-clauses) and som-/Ø-clauses ('which'/'that'/‘who(m)'/Ø-clauses), for example:

(7) Jeg fatter ikke [at/Ø du gider spise på den her restaurant]

'I can't believe [that/Ø you want to dine at this restaurant]'

(8) Den restaurant [som/Ø vi spiste på i sidste uge], er lukket

'The restaurant [which/Ø we dined at last week] is closed'

At and som in such clauses may be seen as near-content-void indexical slot-fillers (for such an analysis of $a t$, cf. Heltoft 1990) whose presence or absence are hardly semantically decisive. Therefore, I refer to these subclauses as at-/Ø-clauses and som-/Ø-clauses, regardless of whether they are realized with or without the initial slot-filler. As will be illustrated, they are distinguished from actual at-clauses and som-clauses by virtue of the non-obligatory nature of at and som.

Finally, by subclause classes I refer to the five comprehensive categories that are the result of my classification criteria as applied to the various subclause types and variants.

\subsection{Distributional properties and criteria}

As discussed in section 2.2., Danish subclauses are typically multifunctional, being able to occur in various syntactic functions of the superordinate clause. Importantly, the specific sets of syntactic functions and positions they can occur in differ from one clause type/variant to another. For instance, returning to da-clauses ('when'clauses), they may, as shown, function as either adverbial, nominal or attributive clauses. Investigating their distributional properties further seems to yield the following pattern: any time clause introduced by $d a$ may function (at least) as an adverbial, a direct object, a prepositional object or an attribute, for example:

(9) Jeg så hendes ansigt [da hun gik forbi]

Adverbial

'I saw her face [when she walked by]'

(10) Jeg så [da hun gik forbi]

'I saw [when she walked by]'

Direct object 
(11) Kan du huske noget fra [da hun gik forbi]?

Prepositional object

'Do you recall anything from [when she walked by]?'

(12) Jeg så hendes ansigt $i$ det фjeblik [da hun gik forbi]

Attribute

'I saw her face the moment [when she walked by]'

Further, when functioning as for example adverbials, $d a$-clauses may occur in the initial position of their superordinate clause, in Danish grammar known as the fundament (e.g. Christensen and Heltoft 2010; Diderichsen 1946; Hansen and Heltoft 2011). They may of course occur in other positions as well, but as the analyses will illustrate, focusing on the fundament position reveals interesting distributional differences. In other words, from a topological point of view (i.e. when focusing on how the constituents are positioned), $d a$-clauses can be said to have the ability to occur in the fundament position:

(13) [Da hun gik forbi], så jeg hendes ansigt

Fundament position '[When she walked by] I saw her face'

A da-clause cannot, however, function as a canonical subject, i.e. a nonextraposed subject (see the definition below), a fact also observed by Hansen and Heltoft (2011: 1502). For example:

(14) *[Da hun gik forbi], var ikke til at glemme '[When she walked by] was unforgettable'

Canonical subject

An at-/Ø-clause, on the other hand, shows different distributional properties: it can easily function as a canonical subject - or as a direct object, a prepositional object or an attribute:

(15) [At du gider spise på den her restaurant], er ikke til at fatte Canonical subject '[That you want to dine at this restaurant] is unbelievable'

(16) Jeg fatter ikke [at du gider spise på den her restaurant]

Direct object 'I can't believe [that you want to dine at this restaurant]'

(17) [At du gider spise på den her restaurant], undrer jeg mig over Prepositional object '[That you want to dine at this restaurant] I'm baffled over'

(18) Det faktum [at du gider spise her], er ikke til at fatte Attribute (appositional) 'The fact [that you want to dine here] is unbelievable'

In addition, two of these examples illustrate the at-/Ø-clause's ability to occur in the fundament position (in (18) it occurs along with the noun phrase 
it is part of). At-/Ø-clauses cannot, however, by themselves function as adverbials ${ }^{5}$ :

(19) *[At du gider spise her], fatter jeg det ikke

Adverbial

'[That you want to dine here] I can't believe it' 6

These are just a few examples of how sets of distributional properties may differ from one clause type/variant to another. Other kinds of subclause material possess yet different distributional properties. Hence, exploring Danish subclauses in terms of: (a) their possible syntactic functions in the superordinate clause, and (b) their possible topological positions in the superordinate clause, yields a plethora of possible and impossible subclause constructions. However, as pointed out in section 3.1., I am only interested in those distributional properties which I find to reflect content features most clearly. Further, in order to reach a sensible level of abstraction, i.e. to avoid approaching a 1:1 level of classification, my analyses will subsume some construction types under more general ones. In particular, I will show that the following five construction types are relevant for classifying the distributional properties of the subclauses: [SUBJECT], [COMPLEMENT], [UNBOUND ADVERBIAL], [ATTRIBUTE] and [FUNDAMENT], the definitions of which are given below.

\subsection{1. [SUBJECT]}

A subclause is said to have the ability to occur as [SUBJECT] if it can function as a canonical subject clause, i.e. a subject clause that is not extraposed but appears in the fundament position (for a discussion of canonical vs. extraposed subject clauses, see Smolka 2005). For example:

(20) [At du gider spise på den her restaurant], er ikke til at fatte Canonical subject '[That you want to dine at this restaurant] is unbelievable'

(20') Det er ikke til at fatte [at du gider spise på den her restaurant] Extraposed subject 'It is unbelievable [that you want to dine at this restaurant]'

(20”) [At du gider spise på den her restaurant], det er ikke til at fatte Extraposed subject '[That you want to dine at this restaurant], that is unbelievable'

\footnotetext{
${ }^{5}$ However, as a near-content-void slot-filler (cf. section 3.3), at is able to co-occur with other conjunctions within, for example, adverbial clauses (cf. for example Heltoft 1990; Pedersen 2009). Further, an adverbial at-clause is treated in section 4.4 .3 - not to be confused with the at-/Ø-clause in question here.

${ }^{6}$ Note that in some examples the English translation does not illustrate the analysis of the Danish example very well. In this case, the Danish example may reasonably be considered impossible but the English translation not necessarily so. As stated in note 2, only Danish examples are analytically accounted for.
} 
(21) *[Da hun gik forbi], var ikke til at glemme Canonical subject (not possible) '[When she walked by] was unforgettable'

(21') Det var ikke til at glemme [da hun gik forbi] Extraposed subject? 'It was unforgettable [when she walked by]'

The subclauses in (20) and (21) are both constructed as canonical subject clauses, but only the at-/Ø-clause actually allows this. A $d a$-clause therefore cannot be said to have the ability to occur as [SUBJECT] even though it might be analysed as an extraposed subject clause, as in (21').

\subsection{2. [COMPLEMENT]}

A subclause is said to have the ability to occur as [COMPLEMENT] if it is able to function as any complement constituent, i.e. any syntactically obligatory constituent governed by the matrix predicate or a preposition, not including canonical subject clauses. Relevant complement constituents include direct object, prepositional object, extraposed subject, subject complement (also known as 'predicative') and bound adverbial, i.e. an adverbial complementing the matrix predicate, for example:

(22) Han boede [som han altid havde boet]

Bound adverbial (manner)

'He lived [as he'd always lived]'

(22') *Han boede

'He lived'

Importantly, in order to feature the [COMPLEMENT] property, subclauses are not required the ability to occur in all the functions mentioned - in principle just one will do, hence the word "any" above.

\subsection{3. [UNBOUND ADVERBIAL]}

A subclause is said to have the ability to occur as [UNBOUND ADVERBIAL] if it is able to function as any optional adverbial, modifying - as opposed to complementing - (part of) the superordinate clause.

\subsection{4. [ATTRIBUTE]}

A subclause is said to have the ability to occur as [ATTRIBUTE] if it is able to function as a postmodifier to any kind of head constituent in the superordinate clause, forming a noun, adverbial or adjective phrase, for example:

(23) Jeg så en mand [som lфbb rundt i pyjamas]

Attribute in noun phrase 'I saw a man [who was running around in his pyjamas]' 
(24) Det faktum [at du gider spise her], er ikke til at fatte Attribute in noun phrase 'The fact [that you want to dine here] is unbelievable'

(25) Jeg så hendes ansigt på et tidspunkt [før hun gik forbi] Attribute in noun/adverbial phrase 'I saw her face at some point [before she walked by]'

(26) Hun var smukkere [end jeg havde forestillet mig] Attribute in adjective phrase 'She was more beautiful [than I had imagined]'

In the above examples, the head constituents are shown in bold type. Note that this, perhaps unusually broad, understanding of "attributive function" encompasses relative clauses as in (23), appositional clauses as in (24) as well as other kinds of attributive clauses as in (25) and (26). For similar broad concepts of attributive/relative clauses, see for example Teleman, Andersson and Hellberg (1999) and Huddleston and Pullum (2002).

\subsection{5. [FUNDAMENT]}

A subclause is said to have the ability to occur in the [FUNDAMENT] if it is able, in at least one function, to occur in the fundament position of the superordinate clause, i.e. immediately before its finite verb - not including for example preposed/left-dislocated subclauses. It is not a requirement that the subclause must occur separately in this position, as attributive subclauses will always occur along with the rest of the phrase they are part of, as for example illustrated in (24) above. Note that the [FUNDAMENT] position is the one required for the [SUBJECT], i.e. the position for canonical subject clauses.

\subsubsection{Overview of distributional properties and criteria}

Hence, any Danish subclause type/variant can be characterized in terms of its ability or inability to occur as [SUBJECT], [COMPLEMENT], [ATTRIBUTE], [Unbound ADVERbial] and [Fundament]. Distinct combinations of distributional properties are characteristic of different subclause types and variants, giving rise to the five-part classification shown in Table 1 , where the + signs indicate which distributional properties are associated with each class. Note that appendix clauses are distinguished by lacking the ability to occur in the [FUNDAMENT] - their syntactic functions vary (as indicated by the + signs in parentheses) and are not criterial for this class. As the five subclause classes exist independently of realized syntactic functions, this qualifies as a classification at material level. In other words, subclauses may be cross-classified in terms of both their material (e.g. semi-nuclear clause) and their realized function in context (e.g. unbound adverbial).

The five classes relate to each other roughly as points on a scale from high to low superordinate clause "integratability", in that for example nuclear clauses can be said to share the ability to integrate completely into the superordinate 
Table 1. Distributional classification criteria

\begin{tabular}{|c|c|c|c|c|c|}
\hline & [SUBJECT] & [COMPLEMENT] & [ATTRIBUTE] & $\begin{array}{c}\text { [UNBOUND } \\
\text { ADVERBIAL] }\end{array}$ & [FUNDAMENT] \\
\hline $\begin{array}{l}\text { 1. Nuclear } \\
\text { clauses }\end{array}$ & + & + & + & & + \\
\hline $\begin{array}{l}\text { 2. Semi-nuclear } \\
\text { clauses }\end{array}$ & & + & + & + & + \\
\hline $\begin{array}{l}\text { 3. Attributional } \\
\text { clauses }\end{array}$ & & & + & & + \\
\hline $\begin{array}{l}\text { 4. Non-nuclear } \\
\text { clauses }\end{array}$ & & & & + & + \\
\hline $\begin{array}{l}\text { 5. Appendix } \\
\text { clauses }\end{array}$ & & $(+)$ & $(+)$ & $(+)$ & \\
\hline
\end{tabular}

clause nucleus, as opposed to appendix clauses at the other end, which can have only limited integration. The scale constitutes a partial implicational hierarchy, where higher-level clauses roughly contain the properties of lower-level clauses but not vice versa. Semantically, the five classes differ from each other in terms of the general meaning relations they establish with their superordinate clause and in terms of semantic layering (cf. for example Dik 1997a; Dik et al. 1990; Engberg-Pedersen et al. 1996; 2005; Hansen and Heltoft 2011; Harder 1996b). Roughly speaking, nuclear, semi-nuclear and attributional clauses can all express part of the representational content (e.g. Dik et al. 1990: 39ff) of the sentence in which they are embedded, as opposed to non-nuclear and appendix clauses, which modify the superordinate clause's interpersonal layers.

In the following analysis section, I define and illustrate each of the five subclause classes with a representative range of authentic Danish examples. However, in order to account for polysemous subclauses, as discussed in section 3.3., I will first outline my criteria for distinguishing different variants of a given subclause type.

\subsection{Focusability vs. non-focusability}

In section 3.4. above, I discussed the distributional properties of temporal $d a$ clauses ('when'-clauses). However, in (27), the $d a$-clause expresses causal rather than temporal meaning:

(27) Jeg kan huske hendes ansigt tydeligt, [da hun gik lige forbi mig]

'I remember her face clearly, [since she walked right past me]'

The two kinds may be regarded as different $d a$-clause variants, one falling into the semi-nuclear class, as we shall see, and the other into the non-nuclear class. Similar polysemy features pertain to a range of other subclause types, including those traditionally analysed as nominal/complement clauses, which calls for separate criteria for distinguishing between the variants. 
A traditional division of adverbial clauses into adjunct clauses and disjunct clauses (e.g. Quirk et al. 1985) is relevant for this purpose. Quirk et al. (1985: 1070) point out that "adjuncts denote circumstances of the situation in the matrix clause, whereas disjuncts comment on the style or form of what is said in the matrix clause... or on its content". Comparing a because-clause with a causal since-clause, they illustrate that the former can be recognized as an adjunct clause due to its focusability, evident from the ability to appear for example in cleft constructions, in the scope of "focusing subjuncts" (e.g. only, just, simply, mainly) or as elliptical answers to focus questions (i.e. wh-questions):

(28) He likes them [because they are always helpful]

Adjunct clause

(28') It's [because they are always helpful] that he likes them

Clefting

(28") He likes them only [because they are always helpful]

Focusing subjunct

(28"') Why does he like them? [Because they are always helpful]

Elliptical answer

Disjunct clauses, such as causal since-clauses, on the other hand, are not focusable and therefore do not have the same constructional potential:

(29) He likes them [since they are always helpful]

Disjunct clause

(29') *It's [since they are always helpful] that he likes them

Clefting

(29") *He likes them only [since they are always helpful]

Focusing subjunct

(29"') Why does he like them? *[Since they are always helpful]

Elliptical answer

(Quirk et al. 1985: 1071)

Hansen and Heltoft (2011: 1541ff) apply similar tests to distinguish Danish adverbial clauses such as temporal $d a$-clauses (adjuncts) and causal $d a$-clauses (disjuncts), and while several more refined accounts of these and related differences have been proposed by others (e.g. Dik 1997a; Haegemann 2006; Van Valin and La Polla 1997; Verstraete 1999; 2005; 2007), I find the general focusability criterion instrumental in distinguishing variants of polysemous subclause types. Indeed, the property of being focusable applies not only to certain adverbial clauses, but to all subclauses (as well as other constituents) that express the representational, rather than interpersonal, content of the sentence they are embedded in (e.g. Dik et al. 1990: 40ff), including nominal/complement clauses. As the treatment of each subclause class will illustrate, most Danish polysemous subclause types feature one variant that expresses representational content and one variant that operates above or outside the representational layer, meaning that focusability testing can disambiguate most polysemous subclauses in context. I employ the "focusing subjunct" test, using Danish focusing subjuncts such as netop ('exactly') and pracis ('precisely') - which are in some instances part of the authentic constructions - as well as the "elliptical answer" test, since I believe 


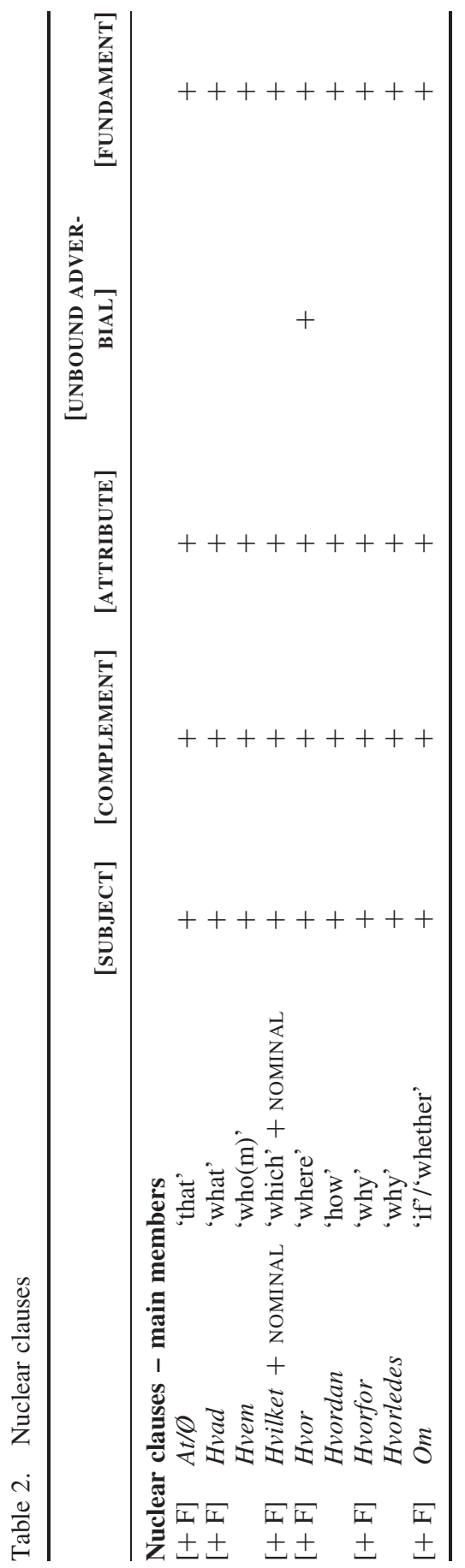


these two tests to be among the least invasive focusability tests. In many cases, I do not explicitly illustrate both tests.

In the following, I present definitions, examples and analyses for each subclause class, accounting for its general characteristics, notable special cases and cases of polysemy. In order to avoid extensive repetition, the weight of examples and discussions decreases towards the later sections. In connection with the discussion and conclusion section (cf. section 9.), an overview of the full classification is provided.

\section{Nuclear clauses}

\subsection{Definition and main members}

Nuclear clauses are distinguished by the ability to occur as [SUBJECT] in the superordinate clause. They feature all the other distributional properties accounted for as well, except for the ability to function as [UNBOUND ADVERBIAL] (apart from hvor-clauses ('where'-clauses); see below). Table 2 lists typical Danish nuclear clause types and variants alphabetically, some preceded by $[+\mathrm{F}]$ to indicate that they are variants distinguished by their focusability (cf. polysemy analyses below); the rest are treated as monosemous clause types.

\subsection{General characteristics}

Nuclear clauses are completely integratable into the superordinate clause nucleus, and function as nominals or as appositional attributes to nominals. They express the content of statements, thoughts, questions, etc. (e.g. Dik 1997a, 52), depending on the matrix predicate or head governing them:

(30) (Korpus DK)

[At en sådan situation er opstået], skyldes utvivlsomt mange ting [SUBJECT] '[That such a situation has arisen] is undoubtedly due to many things'

(31) (BySoc)

jeg ved ikke [om de hed trompetbukser] [COMPLEMENT]-dir.obj.

$£$ de mindede meget om

gamle flådebukser altså sorte med sådan $\sim$ utrolige vide ben...

'I don't know [if they were called trumpet pants] $£$ they were a lot like old navy trousers that is black with these $\sim$ incredibly wide legs...'

(32) (Korpus DK)

Men det har også den fordel, [at CD's standpunkt altid er interessant]

[ATTRIBUTE]appos.

'But this also has the advantage [that CD's point of view is always interesting]' 
(33) (www.philpopculture.dk)

Man kan stille sig selv spørgsmålet, [hvor den etiske granse går mellem tv-studiet og tv-stuen?]

[ATTRIBUTE] -

'You might ask yourself the question [where the ethical appos.

line is drawn between the tv studio and the tv living room?]'

(34) (Korpus DK)

Man kan så blot filosofere over, [hvorvidt [COMPLEMENT] - prep. obj.

CD-løsningen allerede er overhalet af internettet]

'You can then just ponder over [whether the CD solution

has already been overtaken by the internet]'

(35) (Korpus DK)

Men [hvor det så kommer fra], har man [COMPLEMENT] + [FUNDAMENT]

endnu ikke fastslået

'But [where that then comes from], no one has yet determined'

(36) (www.linux-nerd.blogspot.com)

og man kan meget lettere se, [hvad at man downloader],

[COMPLEMENT]

[hvor hurtigt at man downloader/uploader], og [hvem at

man downloader fra]

'and you can much more easily see [what you are downloading], [how fast

you are downloading/uploading], and [whom you are downloading from]'

\subsection{Special cases}

Nuclear clauses include the $a t$-/Ø-clause, which - as discussed - may or may not be introduced by at:

(37) (BySoc)

jeg tror også jeg tror [jeg vil spare mig selv for ulejligheden]

'I also think I think [I will spare myself the trouble]'

(37’) jeg tror også jeg tror [at jeg vil spare mig selv for ulejligheden]

'I also think I think [that I will spare myself the trouble]'

A particular at-/Ø-clause construction worth mentioning is the degree-indicating construction in which the subclause expresses the degree of something presented in the superordinate clause, for example:

(38) (grimme-aelling.dk)

"Oh Gud ske lov!" sukkede allingen, "jeg er så styg, [at selv hunden ikke gider bide mig]!"

"“Oh thank God!" the duckling sighed, "I am so ugly [that even the dog won't bite me]!"” 
This kind of construction is discussed by for example E. Hansen (1998), who treats it as an adverbial clause construction due to its semantic resemblance to degree adverbials. However, since the subclause functions as postmodifier to a head in the superordinate clause - i.e. så styg ('so ugly') - I consider it more appropriate to analyse the subclause as attributive. In this respect, it may be said to resemble appositional clauses, for example:

(38') Jeg er af den overbevisning, [at selv hunden ikke gider bide mig] 'I have the conviction [that even the dog won't bite me]'

A fact supporting this analysis is that the subclause itself cannot be placed in the fundament position, which is an option for most adverbial clauses:

(38") *[at selv hunden ikke gider bide mig], er jeg så styg

'[that even the dog won't bite me], I am so ugly'

The rest of the subject-complement constituent has to move along, supporting the argument that the subclause functions as [ATTRIBUTE], more precisely as part of an adjective phrase:

(38"') Så styg, [at selv ikke hunden gider bide mig], er jeg

'So ugly [that even the dog won't bite me] am I'

Note that at is indeed also facultative in such degree constructions:

(39) (dindebat.dk)

Jeg er godt nok så træt [jeg ikke kan hange sammen], men jeg har ikke

lyst til at tage medicin under min graviditet, selvom sovesattet skulle

vare ufarligt for barnet.

'I'm actually so tired [I can't keep it together], but I don't want to take medicine during my pregnancy, although the sleeping kit should be harmless to the child'

It might be added that a similar and nearly synonymous degree clause construction can be realized with semi-nuclear så-clauses ('so'-clauses), cf. section 5.3.

Another special case is hvor-clauses, since they are able to function as [UNBOUND ADVERBIAL] as opposed to other nuclear clauses - i.e. as a place adverbial:

(40) (www.janussen.dk)

[Netop hvor vi stod] var der så stejlt, at en del biler gik $i$ stå, da de kom dertil

'[Exactly where we were standing] it was so steep that several cars stalled when they got there'

While I will not elaborate much on this anomaly, it is worth mentioning that the [ATTRIBUTE] function of the hvor-clause is a common relative clause construction in Danish, in which the hvor-clause can modify superordinate heads in more or less abstract ways, not necessarily in spatial relations (as also 
discussed in Hansen and Heltoft 2011: 1525f) - note for example how a hvorclause can correspond to an English relative when-clause:

(41) (BySoc)

så blev man altså hangende selv om der nok har varet tidspunkter [hvor man godt

kunne have toenkt sig at komme ud] ik'

'then you would stay there even though there were probably times [when you would have liked to get out] right'

\subsection{Cases of polysemy}

As indicated in the chart, nuclear clauses - apart from hvor-clauses - cannot function as [UNBOUND ADVERBIAL], or other kinds of adverbials. However, they have counterpart variants that can, i.e. clauses that look the same but have different content and distributional properties.

\subsubsection{Om-clauses}

$\mathrm{Om}$-clauses come in two variants, the nuclear variant mentioned above, and a non-nuclear variant that has adverbial function. The latter is sometimes described as a kind of conditional clause synonymous to hvis-clauses (Hansen and Heltoft 2011: 1552), but in modern standard Danish this meaning is basically fossilized, as opposed to an 'even-if'-like meaning (often co-triggered by the adverbial så ('then')), for example:

(42) (BySoc)

nå men altså fodbold det spiller jeg endnu ik’ det tror jeg aldrig jeg slutter med [om jeg så bliver halvfems der]

'well but anyway football I still play right I think I'll never stop that [regardlessif I then turn ninety there]

While the nuclear om-clause variant is focusable, the non-nuclear variant is not:

(43) (www.borisolander.dk)

du kan have gode kort eller lidt dårligere kort på hånden, men [praecis om du ender med at få 7 eller

Focusable $=$ nuclear clause 10 stik] kommer an på ting du ikke kan forudsige 'you might hold good cards or less good cards, but [precisely whether you end up with 7 or 10 tricks] depends on things you cannot predict'

(43') A: Hvad kommer an på ting du ikke kan forudsige? 'What depends on things you cannot predict?'

B: [Om du ender med at få 7 eller 10 stik] Focusable $=$ nuclear '[Whether you end up with 7 or 10 tricks]' clause 
$\left(42^{\prime}\right)$

$\ldots *$ det tror jeg aldrig jeg slutter med

Non-focusable $=$ non-nuclear [netop om jeg så bliver halvfems der] clause

'... I think I'll never stop that [exactly regardless-if

I then turn ninety there] $\sim$

It is hardly possible to construct a meaningful piece of dialogue in which the nonnuclear om-clause appears as an elliptic answer. This further supports the status of the om-clause as non-focusable.

\subsubsection{Hv-clauses}

Some $h v$-clauses match the criteria for appendix clauses rather than nuclear clauses, again due to polysemy. Nuclear $h v$-clause variants may be characterized as interrogative clauses, designating questions that may be for example posed, announced or commented on in the superordinate clause:

(44) (BySoc)

jeg ved ikke [hvorfor jeg aldrig har gået $i$ børnehave] $£ £ \quad$ Nuclear clause

'I don't know [why I never went to kindergarten] $£ £$ (question)

Their appendix counterparts, on the other hand, designate individual statements elaborating on the superordinate clause content, for instance by presenting something as the result of it:

(45) Vi boede på landet, [hvorfor jeg aldrig har gået $i$

Appendix clause

børnehave]

(result)

'We lived in the country, [which is why I never went to kindergarten]'

Again, the variants are distinguished through focusability testing, such that the nuclear variants are focusable and the appendix variants are not:

(44') Jeg ved ikke [pracis hvorfor jeg aldrig har gået $i$

Focusable $=$ nuclear børnehave] clause

'I don't know [precisely why I never went to kindergarten]'

(44") A: Hvad ved du ikke?

'What don't you know?'

B: [Hvorfor jeg aldrig har gået $i$ børnehave]

'Why I never went to kindergarten'

Focusable $=$ nuclear

clause

(45') *Vi boede på landet, [pracis hvorfor jeg aldrig $\quad$ Non-focusable = appendix har gået i børnehave]

clause

'We lived in the country, [precisely which is why

I never went to kindergarten]'

(45”) A: Hvad var resultatet af at I boede på landet?

'What was the result of you living in the country?'

B: *[Hvorfor jeg aldrig har gået i børnehave] $\quad$ Non-focusable $=$ appendix

'Which is why I never went to kindergarten'

clause 
Another $h v$-clause-related issue deserves a comment. Some $h v$-clauses may occur as what is known as "free" (or "headless") relative clauses (e.g. Dik 1997b: 80ff) or, in the Danish grammar tradition, "almene" (roughly, 'general') relative clauses (e.g. Diderichsen 1957[1946]: 210; Hansen and Heltoft 2011: 1537-9), for example:

(46) (www.fdm-travel.dk)

Man tager [hvad der bliver serveret], men det er til

Direct object gengald fantastisk

'You take [what is served], but then it's fantastic'

Contrary to what these labels suggest, this clause function is not relative, but nominal or in certain cases adverbial. Hansen and Heltoft do emphasize the nominal and adverbial functions but still support the notion that they are realized by what is formally relative clauses (Hansen and Heltoft 2011: 1538). However, relative, nominal and adverbial clauses are categories at the level of function: which means one cannot be said to realize the other - clause material is what realizes clause functions. For characterizing the kind of clause material that "free relative clauses" are realized by, I find their similarity with interrogative $h v$ clauses, i.e. nuclear $h v$-clauses, more relevant than their alleged "relativeness" (a similarity also emphasized by Dik 1997b: 80ff), which may be illustrated by juxtaposing (47), (48) and (49):

(47) Ved du [hvem der kommer i aften]?

Interrogative clause

'Do you know [who is coming tonight]?'

(48) Du må huske at hilse [hvem der kommer i aften]

'Free relative clause'

'Please say hello to [who(-ever) is coming tonight]'

(49) Du bliver glad for [hvem der kommer $i$ aften]

'Free relative clause'

'You'll be thrilled about [who is coming tonight]'

In (47), the question may either be interpreted as a genuine request for knowledge, in which case the interrogative subclause has unspecific reference, or as a "quiz" question, in which case the subclause may refer to a specific person. In (48) and (49), similar gradings between non-specific and specific reference are illustrated. These similar $h v$-clauses all function as nominals, whose reference may be given in more or less specific terms, depending on the context and the type of governing matrix predicates. Thus, I regard them as nuclear clauses on a par with interrogative $h v$-clauses.

However, one subgroup resembling "free relative clauses" do not share the nominal quality of the ones discussed. In particular, non-focusable $h v$-clauses featuring the adverbial end (roughly, 'ever') or an initial uanset, ligegyldigt or

\footnotetext{
${ }^{7}$ There is likely to be diachronic evidence in favour of the "relative" account, but this study takes a purely synchronic perspective on subclause classification.
} 
lige meget (roughly, 'regardless'), etc. may function as [UNBOUND ADVERBIAL], i.e. breaching the nuclear clause criteria:

(50) (www.mogensagerbo.dk)

Alle mennesker er lige vardifulde, [hvordan de

[UNBOUND ADVERBIAL] end har levet]

'All people are equally valuable, [regardless how they have lived]'

(51) (www.kofoedsskole.dk)

[Uanset hvorfor man kommer på Kofoeds Skole],

[UNBOUND ADVERBIAL] er skolen ikke en endestation

'[Regardless why you come to Kofoeds Skole], the school is not a final destination'

As mentioned, such clauses are non-focusable:

$\left(50^{\prime}\right) *$ Alle mennesker er lige vardifulde, [netop hvordan de Non-focusable end har levet]

'All people are equally valuable, [exactly regardless how they have lived]'

(51') *[Netop uanset hvorfor man kommer på Kofoeds Skole],

Non-focusable er skolen ikke en endestation

'[Exactly regardless why you come to Kofoeds Skole],

the school is not a final destination'

Constructing the above subclauses as meaningful elliptical answers is impossible, further supporting the fact that they are non-focusable - as also illustrated they are able to occur in [FUNDAMENT], which leaves only the criteria of non-nuclear clauses satisfied.

Thus, certain $h v$-clauses divide into as many as three variants: one set of variants are focusable, and classified as nuclear clauses. There are two nonfocusable variants, which are distinguished such that one set features special elements like end, uanset, ligegyldig, etc. and are classified as non-nuclear clauses, while the other do not - in fact cannot - feature such elements, and are classified as appendix clauses.

\subsubsection{At-clauses}

Finally, clauses introduced by at may occur in a highly archaic adverbial function designating purpose:

(52) (Mikkelsen 1911: 517)

Kom herhen, [at vi kan snakke lidt sammen]

'Come over here, [that we can talk a bit]' 


\section{(53) (Korpus DK)}

Han har svøbt skфrtet om knaene og lagt albuen på pergamentet, [at ikke vinden skulle spille med det]

'He has wrapped the skirt around his knees and rested his elbow on the parchment, [that the wind should not play with it]'

This adverbial function is realized not by a nuclear at-/Ø-clause but by an appendix at-clause. In other words, they are different clause types rather than variants, since the appendix clause at may be regarded as an actual conjunction, which is obligatory, whereas the nuclear clause at is rather to be seen as a slot-filler that may or may not be present. While I regard the obligatory vs. optional status of at as the basic criterion for distinguishing the two clause types, they seem to also differ with respect to their focusability features:

(54) (Korpus DK)

Det exceptionelle er jo ikke så meget, at Focusable $=$ nuclear clause dronning Margrethe er et menneske, men [netop at hun er dronning]

'The exceptional is not so much that queen Margrethe is a human being, but [exactly that she's a queen]'

(52') *Kom herhen, [netop at vi kan snakke Non-focusable $=$ appendix clause lidt sammen]

'Come over here, [exactly that we can talk a bit]'

\section{Semi-nuclear clauses}

\subsection{Definition and main members}

Semi-nuclear clauses are distinguished by featuring all the distributional properties accounted for, except the ability to function as [SUBJECT]. As shown in Table 3, however, two members fail to meet one of the criteria, i.e. fordi- and uden (at)-clauses, to which I will return below.

\subsection{General characteristics}

As their name indicates, semi-nuclear clauses are only partially "allowed" in the superordinate clause nucleus. These are all subclauses typically labelled adverbial clauses, more specifically adjunct clauses, as the adverbial function is traditionally considered to be their "default" function. A considerable number of the semi-nuclear clauses have temporal meaning, while others specify for example manner, purpose, cause or condition in relation to what is described in the superordinate clause. 


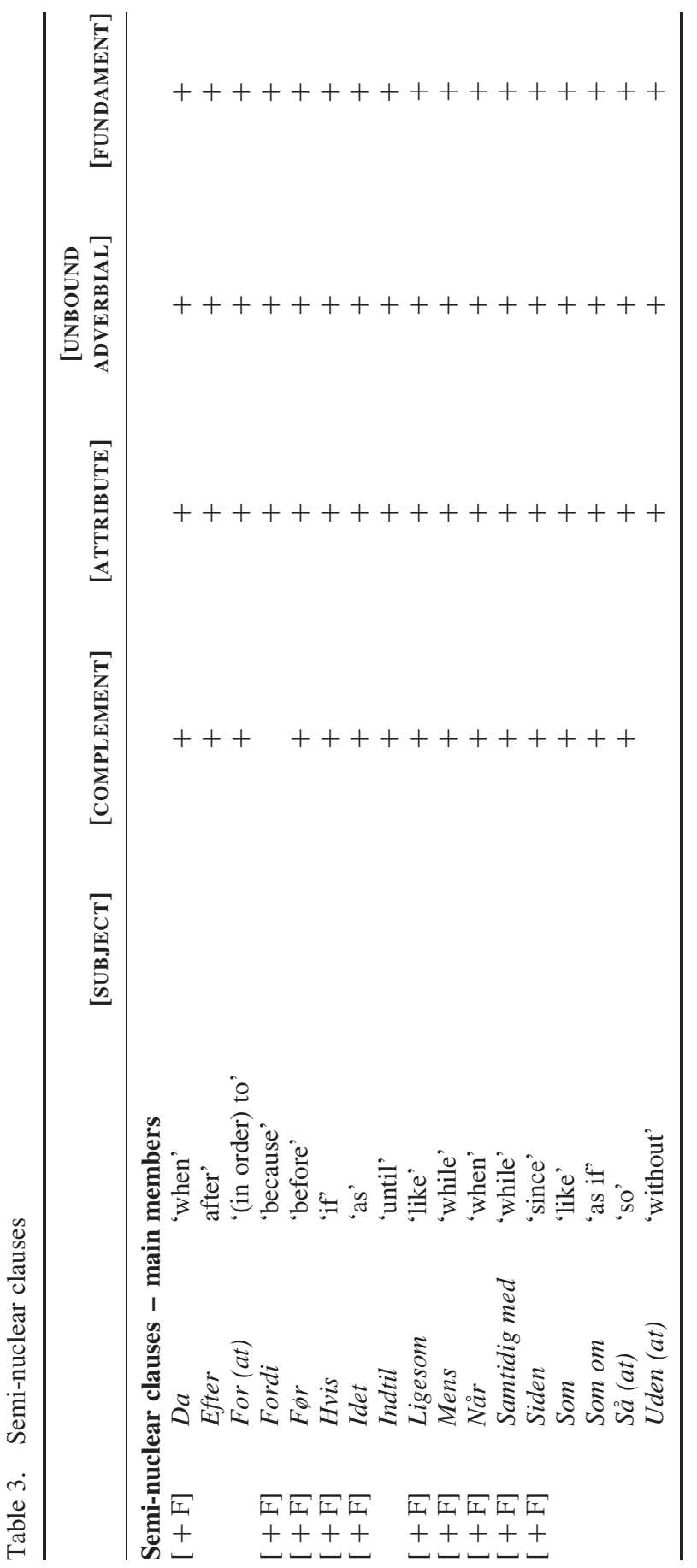


Semi-nuclear clauses share the ability, among others, to occur as [COMPLEMENT]. Some semi-nuclear clauses have more limited complement possibilities than others because they only meet the lexical restrictions of a few matrix predicates or prepositions. For example, as discussed earlier, semi-nuclear $d a$-clauses may occur as basically any kind of [COMPLEMENT] (given the right context), whereas semi-nuclear siden-clauses are for instance hardly able to function as direct objects:

(55) (BySoc)

jeg kan (da) i hvert fald huske [da jeg gik i forste

Direct object

klasse og $\sim$ sådan noget]

'I do at least remember [when I went to first grade and $\sim$ stuff like that]'

(55') *jeg kan (da) i hvertfald huske [siden jeg gik iførste klasse og og sådan noget]

'I do at least remember [since I went to first grade and $\sim$ stuff like that]'

The potential of semi-nuclear siden-clauses as [COMPLEMENT] is limited to certain prepositional object constructions and bound adverbial constructions, for example:

(56) (http://www.e-pages.dk/mariager_avis_dk)

Louise har fra [siden hun var lille] brugt meget

Prep.object

tid på danseskole og tuneringer, men med tiden blev

det svart at få tid til både arbejde og dans.

'Louise has, from [since she was little], spent a lot of time at dancing school and tournaments, but in time it became hard to find the time for both work and dancing.'

(57) (camping.vores-forum.dk)

Vi er ganske forundrede over at vores 5 liters

Bound adverbial

gasflaske har varet [siden vi købte vognen i 2009]...

'We are quite astonished that our 5-liter gas cylinder

has lasted [since we bought the camper in 2009]...'

Importantly, what is criterial is the ability to occur as [COMPLEMENT] as such. Below, a few other examples are presented to illustrate how semi-nuclear clauses, such as hvis-clauses, som-clauses, som om-clauses and så-clauses, can actually occur in [COMPLEMENT] functions and [ATTRIBUTE] functions, properties not commonly discussed in the literature:

(58) (BySoc)

og vi lå og lyttede ££ for der havde vi sådan at vi [COMPLEMENT] - dir. obj.

kunne hore [hvis folk kom sent hjem] $£$

'and we lay there listening $£ £$ 'cause it was

like $\sim$ we could hear [if people came home late] £' 
(59) (www.marsh.dk)

Har din virksomhed overblik over sine mest kritiske kontraktsrisici og konsekvensen, [hvis de aktualiseres]? (the subclause modifies 'Is your company aware of its most critical contract a nominal, not the full risks and the consequence [if they are actualized]?' superordinate clause)

(60) (BySoc)

og så fordi $\sim$ han $\sim$ altså han gjorde [som det

[COMPLEMENT] - bound adv. passede ham] $i k$

'and then 'cause $\sim$ he $\sim$ you know he did [as it pleased him] right'

(61) (www.netting.dk)

Vejledninger [som du foretrakker det]

[ATTRIBUTE]

'Guidelines [as you prefer it]'

(62) (www.altfordamerne.dk)

Hvad stiller man op med en mor i 70'erne,

[COMPLEMENT] - bound adv.

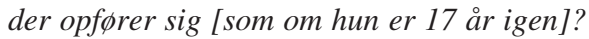

'How do you deal with a mother in her 70's who behaves [as if she is 17 again]?'

(63) (www.martinøstergaard.dk)

Han har en opførsel [som om han er guds

[ATTRIBUTE] gave til kvinden].

'He has a behaviour [as if he is god's gift to women].'

(64) (www.fenderen.dk)

Hvad skal man bruge den til hvis man

[COMPLEMENT] - bound adv.

ikke bor [så man har adgang til vandet]?

'What can you use it for if you don't

live [so you have access to the water]?'

(65) (www.kirkeogfilm.dk)

Det er en ensomhed, som er forbundet med et

[ATTRIBUTE]

talent, [så man tror, det er logn]

'It is a loneliness which is tied to a talent [so you

won't believe it]'

\subsection{Special cases}

As noted, fordi-clauses and uden (at)-clauses stand out by not being able to function as [COMPLEMENT]: 
(66) *Det skyldes [fordi det er kvinder $i$ en høj uddannelse]

'The reason is [because they are women of high education]'

(67) *Jeg foretrakker [uden at det bliver for meget $]^{8}$

'I prefer [without that it gets too much]'

At a glance, this disqualifies them as semi-nuclear clauses and puts them in the non-nuclear class. Yet they behave like adjuncts, in that they are both focusable. Adjuncts operate on the representational layers of their superordinate clause and are as such different from non-nuclear clauses:

(68) (BySoc)

så £ går kvinden derhjemme et halvt år ekstra ik' det er

Focusable

lidt surt at opleve \# altså [netop fordi det er kvinder $i$ en

høj uddannelse] $£ £ £$

'then $£$ the woman stays at home for an extra half year right it's

a bit vexing to experience \# you know [exactly because they are

women of high education]'

(69) (www.heste-nettet.dk)

Ja Emma er normalt også enormt arbejdsom og

Focusable

fremadgående, men [netop uden at det går over $i$ at

vare varm eller vild.]

'Yes Emma is normally very hard-working and forward-going,

but [exactly without that it turns into being warm or wild.]'

In other words, they behave partly like non-nuclear clauses, and partly like seminuclear clauses. However, both fordi- and uden-clauses can in certain contexts occur as attributes to nominal heads:

(70) (www.hk.dk)

Ganske vist indeholder lovforslaget et forbud

[ATTRIBUTE]

mod fyring [fordi man siger nej til at gå på deltid]...

'Of course, the proposed legislation involves prohibition of

dismissal [because you say no to going part-time]...'

\footnotetext{
${ }^{8}$ Note that a certain idiomatic copula construction allows e.g. fordi-clauses to occur in [COMPLEMENT]-like functions, such as Det er [fordi det er kvinder i en høj uddannelse] ('It is [because they are women of high education]'). This construction requires a fixed superordinate construction of the kind: det er ('it is'), which also seems to allow constructions like $O g$ det var [selvom det var m $\phi r k t$ ] ('And that was [although it was dark]'). etc. Characteristically, the sole function of the superordinate clause is to link the subclause anaphorically to some previous proposition, which is the actual one modified by the subclause. In other words, I treat such clause occurrences as peripheral examples of [UNBOUND ADVERBIALS]. For a subclause to qualify as having [COMPLEMENT] ability, it must have the ability to be governed by lexical items in the superordinate clause (as opposed to just for example copula verbs).
} 
(71) (www.buschauffor.dk)

Frisk kørsel [uden at man bliver kastet frem og tilbage i sadet], [ATTRIBUTE] chaufforen er god til at laese trafikken.

'Fresh driving ${ }^{9}$ [without that you get thrown back and forth in your seat], the driver is good at reading the traffic.'

The fordi-clause and the uden (at)-clause cannot be said to modify more than the nominals preceding them. The fact that the two clauses feature this vague ability to function as [ATTRIBUTE] suggests that they are above non-nuclear clauses in the "superordinate clause integratability" hierarchy (cf. section 3.4.6), and although they might more appropriately be said to constitute a separate class altogether, I find it reasonable to include them as (somewhat peripheral) semi-nuclear clauses.

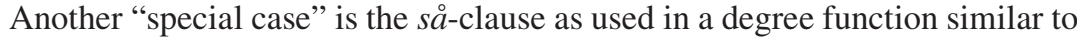
that of the degree nuclear clause, i.e. an [ATTRIBUTE] function:

(BySoc)

og lige pludselig så stak han det der hoved ud de blev sgu så forskraekkede

[så de sprang $i$ havnen dernede]

'and then all of a sudden he stuck out that head they got so freaked out [so

they jumped into the harbour down there]'

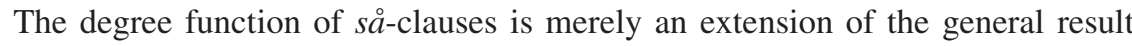
meaning shared by så-clauses, in that the result of the superordinate situation is used to indicate the degree of what it measures.

\subsection{Cases of polysemy}

Like nuclear clauses, all semi-nuclear clauses are focusable, which is instrumental in the disambiguation of polysemous cases.

\subsubsection{Temporal/non-temporal clauses}

Most so-called temporal clauses, such as mens-, siden-, f $\phi r-$, når-, da-, samtidig med-, ligesom-clauses etc., have non-temporal counterparts, for example causal or adversative variants of the same clause material (cf. Mortensen 2006). While the temporal variants meet the criteria for semi-nuclear clauses, the non-temporal variants are generally non-nuclear clauses:

(73) (www.mygreenland.dk)

... og vi var heldige, for [netop mens vi

Temporal variant

var der], brakkede der et kampe stykke is $\quad$ Focusable = semi-nuclear clause af gletsjeren...

\footnotetext{
${ }^{9}$ Note that 'driving' is a somewhat misleading translation (although there is no obvious alternative), as it may read as a verb in the present participle, rather than a noun. The Danish words kørsel and fyring can only be nouns.
} 
'... and we were lucky, because [exactly while we were there], a huge piece of the glacier broke off ...'

(74) (BySoc)

os der havde det vi fik lov til at beholde det [mens at Non-temporal variant de nye der kom] $£$ de de fik altså ikke noget...

'us who had it we were allowed to keep it [while the new folks arriving $£$ they they didn't get anything]'

(74') *os der havde det vi fik lov til at beholde Non-focusable $=$ non-nuclear $\mathrm{cl}$. det [netop mens at de nye der kom] $£$ de de fik altså ikke noget 'us who had it were allowed to keep it [exactly while the new folks arriving $£$ they they didn't get anything]'

(75) (BySoc)

men $\sim$ han kommer hertil [f $\phi r$ han er to år] $i$ hvert fald $£ £ \quad$ Temporal variant 'but $\sim$ he comes here [before he is to two years old] definitely $£ £ '$

(75') han kommer hertil [netop før han er to år] Focusable = semi-nuclear cl. $i$ hvert fald he comes here [exactly before he is two years old] definitely'

(75") A: Hvornår kommer han hertil?

'When does he come here?'

$\mathrm{B}$ : [F $\phi r$ han er to år] Focusable $=$ semi-nuclear $\mathrm{cl}$. '[Before he is two years old]'

(76) (www.sol.dk)

Jeg har altid varet stolt over at fortalle om DK og de Non-temporal variant rettiheder vi har når jeg rejser til et muslimsk land... men $i$ фjeblikket bør jeg nok holde min kaft [før jeg blir halshugget offenligt]. 'I have always been proud to talk about DK and the rights we have when I travel to a muslim country... but at the moment I guess I should shut up [before I get decapitated in public].'

(76') ??men i фjeblikket bør jeg nok holde min $\quad$ Non-focusable $=$ non-nuclear cl. kaft [netop for jeg blir halshugget offenligt] 
'but at the moment I guess I should shut up [exactly before I get decapitated in public].'

(76") A: Hvorfor bør du holde din kaft? Non-focusable $=$ non-nuclear $\mathrm{cl}$. 'Why should you shut up?'

B: ??[Fфr jeg blir halshugget offenligt]

'[Before I get decapitated in public]'

As mentioned earlier, hvor-clauses also have a non-nuclear variant, which is illustrated in 7.3 below.

\subsubsection{Som-clauses}

A clause introduced by som may either represent the semi-nuclear som-clause type, and designate comparison or time, or the attributional som-/Ø-clause type, and designate specifications about a nominal in the superordinate clause. Since the focusability criterion is not straightforwardly applied in attributive contexts, I simply distinguish between the two types based on the obligatory or nonobligatory nature of the conjunction:

(77) (www.vip.tv2.dk)

Den store skuespillerinde døde i går, Obligatory 'som'= semi-nuclear clause 83 år gammel, omgivet af sine bedste venner og familien - [pracis som hun фnskede det].

'The great actress died yesterday, 83 years old, surrounded by her best friends and her family - [precisely as she wanted it].'

(78) (BySoc)

så gik jeg ned og hentede en eller Non-obligatory 'som' = attributional clause anden god film [som jeg vidste

han gerne ville se]...

'then I went down and picked up some good movie [which I knew he'd like to watch]...'10

\footnotetext{
${ }^{10}$ In contexts where the superordinate head constituent correlates with the subject of the subclause (as opposed to for example a direct object as in (78)), omission of som requires insertion of der as a dummy subject, cf. example (84') below.
} 


\subsubsection{Hvis-clauses}

Further, the hvis-clause type has a semi-nuclear and a non-nuclear variant, the latter being non-focusable. The semi-nuclear hvis-clause designates an objective condition, i.e. an antecedent for a superordinate clause consequent, whereas the non-nuclear variant expresses conditional meaning of a more abstract nature:

(79) (BySoc)

nej $£$ det generere ikke så meget tror jeg $£$

[kun hvis der er meget $r \phi g$ ] $£$

Objective condition

'no $£$ it doesn't bother a lot I guess $£$

[only if there is a lot of smoke] $£^{\prime}$

(80) (BySoc)

de udgjorde sådan en $\sim$ sådan en

Abstract conditional meaning

dukkelisegruppe [hvis du kan forstå mig]

'they were something like $\sim$ like a doll club

[if you understand me]'

(80') *de udgjorde en $~$ en sådan en

Non-focusable $=$ non-nuclear clause

dukkelisegruppe [kun hvis du kan

forstå mig]

'they were something like $\sim$ like a doll

club [only if you understand me]'

Constructing the non-nuclear hvis-clause as an elliptical answer to a question is hardly possible, further illustrating its non-focusability.

\subsubsection{Fordi-clauses}

Finally, fordi-clauses - and their English equivalent, because-clauses - are shown in several studies to have a number of more or less distinct variants (e.g. Hengeveld 1998; Therkelsen 2003; Verstraete 2007). Within this framework, I treat fordi-clauses as a type containing two variants: the semi-nuclear variant already discussed, and an appendix clause variant, for example:

(81) (BySoc)

ja sådan du ved at de var sådan lidt mere fordi $£$ \# at de kunne

tillade sig mere ik' [fordi der var jo granser for hvad min mor

hun kunne tillade os] $£$

'yes $\sim$ like you know they were a bit more because $£$ \# they were allowed

more right [because there were of course limits to what my

mum could allow us] $£^{\prime}$

In this kind of fordi-clause, the speaker expresses an explanation/justification for making the statement contained in the superordinate clause, rather than a causal reason for its content. I regard this as an appendix clause variant since such 
Table 4. Attributional clauses

[UNBOUND

[SUBJECT] [COMPLEMENT] [ATTRIBUTE] ADVERBIAL] [FUNDAMENT]

\begin{tabular}{llcc}
\hline Attributional clauses - main members & & \\
End & 'than' & + & + \\
Som/Ø & 'which'/ & + & \\
& 'that'/ & & \\
& 'who(m)'/Ø & & \\
\hline
\end{tabular}

fordi-clauses cannot occur in the [FUNDAMENT] position without a crucial change of meaning:

(81') ??[fordi der var granser for hvad min mor kunne tillade os] kunne de tillade sig mere

'[because there were limits to what my mum could allow us] they were allowed more'

If forced into the [FUNDAMENT] position, the fordi-clause can only designate the causal reason for the content of the superordinate clause, which would effectively turn it into a semi-nuclear fordi-clause variant.

\section{Attributional clauses}

\subsection{Definition and main members}

Attributional clauses are distinguished by their inability to function as anything but [ATTRIBUTE]. They can occur in the [FUNDAMENT] position together with the rest of the phrase in which they are postmodifiers (Table 4).

\subsection{General characteristics}

Attributional clauses form a very small subclause class containing two main members: the comparative end-clause and the som-/Ø-clause, i.e. the traditional "relative" clause. Their only function is to modify other clause constituents, and semantically this is done in quite different ways, as I will illustrate below. In other words, their shared content element is therefore of a fairly abstract nature and may be characterized as "comparison" in a broad sense.

\subsection{End-clauses}

Any subclause introduced by end satisfies the criteria of attributional clauses because it can only function as [ATTRIBUTE]. End-clauses modify adjectives or adverbs in the comparative, or other kinds of heads that may subject the superordinate clause content to comparison: 
(82) (BySoc)

der var sammenholdet meget storre [end det er nu] nu er vi jo vokset lidt fra hinanden

'the team spirit was much bigger [than it is now] now we have grown somewhat apart'

(83) (BySoc)

altså jeg har al-aldrig kendt andet [end at min bedste har boet hos os] ££ 'you know I have ne- never known anything else [than that my granny has been living with us] $\mathfrak{e}$ '

The fact that end-clauses are attributive and not adverbial, as some studies tend to argue (e.g. Teleman, Andersson and Hellberg 1999: 470, concerning 'än'), is illustrated by their inability to occur separately, i.e. without the rest of the phrase they are part of, for example:

(82') *[End det er nu], var sammenholdet meget st $\phi r r e$

'[Than it is now], the team spirit was much bigger'

(82") [Meget større end det er nu], var sammenholdet

'[Much bigger than it is now] was the team spirit'

\subsection{Som-/Ø-clauses}

Like end-clauses, som-/Ø-clauses are [ATTRIBUTES], functioning as postmodifiers in nominal phrases. However, a subclause introduced by som may also be a semi-nuclear som-clause. As mentioned, I treat them as two different clause types, one featuring an obligatory som (semi-nuclear) and one featuring a nonobligatory som (attributional):

(84) (BySoc)

jeg legede faktisk mest med med med dem [som som var $i$ gaden] £ også efter jeg var kommet i skole

'I did in fact play mostly with with with those [who who were in the street] $£$ even after I started school'

In (84), the subclause is attributional because som is non-obligatory - note that leaving it out requires insertion of the dummy subject der, as mentioned in note 10 above:

(84') jeg legede faktisk mest med dem [Ø der var i gaden]

'I did in fact play mostly with those [Ø DUMMY SUBJECT were in the street]'

That the der-construction does not amount to a different subclause type follows from the fact that the dummy subject can easily be present simultaneously with som: 
(84") jeg legede faktisk mest med dem [som der var i gaden]

'I did in fact play mostly with those [who DUMMY SUBJECT were in the street]'

The optionality of som applies in both restrictive and parenthetical constructions, although most parenthetical constructions do feature som (and/or the dummy subject). In (85) below, the parenthetical relative clause is indeed introduced by som, while in (86) it is not:

(85) (www.ezz.dk)

Er DSB, [som i $\emptyset v$ rigt intet har med sporene vedligehold at gøre],

bedre $i$ stand til at vurdere sporenes tilstand?

'Is DSB, [who by the way has nothing to do with track maintenance],

better suited to assess the condition of the tracks?'

(86) (www.feltet.dk)

Her lagde DCU's formand Tom Lund og direktør Jesper Worre afstand til bogen, [de i фvrigt ikke havde laest forinden]...

'Here, DCU chairman Tom Lund and Director Jesper Worre

disacknowledged the book, [they by the way hadn't read beforehand] ...'

The som-/Ø-clause and its semi-nuclear counterpart, which may generally be characterized as a comparison clause, are semantically related, which may be illustrated by juxtaposing two identically formed som-clauses, one from each class:

(87) (www.aegteskabudengraenser.dk)

Hvis en eller begge af jer er under 24 år, så er

Semi-nuclear clause

den nuvarende 24-års regel et problem, [som du

selv er inde på]

'If one or both of you are under 24 years, then the

current 24-year rule is a problem, [as you mention

yourself]'

(88) (www.gipote.dk)

De store racer HAR jo yderligt det problem, [som du Attributional clause selv er inde på] - at de er så sent udviklede både

fysisk og psykisk.

'The large breeds DO moreover have the problem

[which you mention yourself] - that they mature

so late both physically and mentally.'

The som-clause in (87) is recognized as a semi-nuclear clause due to the conjunctional's obligatory status, while the one in (88) does not require the som and is therefore an attributional clause. Yet, the subclauses share the comparison element - the main difference being that in (87) the comparison concerns the entire superordinate clause, whereas in (88) it is restricted to concerning the 
nominal head. As mentioned, comparison is also an essential meaning component of end-clauses, and may therefore be regarded a general content feature of attributional clauses. Attributional clauses may, depending on the construction they are part of, operate on the representative or the interpersonal layers of the superordinate clause.

\section{Non-nuclear clauses}

\subsection{Definition and main members}

Non-nuclear clauses are distinguished by their inability to function as anything but [UNBOUND ADVERBIAL]. They may moreover occur in the [FUNDAMENT] position. Non-nuclear clauses are non-focusable, as indicated by [-F] in Table 5 (those with no focusability indication are treated as monosemous - they too are non-focusable).

\subsection{General characteristics}

Like semi-nuclear clauses, non-nuclear clauses are clauses usually treated as adverbial clauses - and in this case well justified, as they indeed only function as adverbials. While semi-nuclear clauses (in adverbial function) were characterized as adjuncts above, non-nuclear clauses are disjuncts, expressing subjective circumstances, such as reason, reservation, opposition, explanation, etc.

\subsection{Cases of polysemy}

As discussed in the treatment of semi-nuclear clauses, the non-temporal counterparts to temporal clauses are generally non-nuclear clauses, for example adversative mens-clauses and causal-like $d a-$, når-, før- and siden-clauses. Further, as discussed in the treatment of nuclear clauses, non-focusable variants of $h v$-clauses, typically featuring elements such as the adverbial end or the initial modifiers uanset, ligegyldig, lige meget, etc., fall within the non-nuclear class. Typically, they express concessive relations, i.e. they stress the inevitability of what is presented in the superordinate clause despite more or less specific obstacles, for example:

(89) (www.b.dk)

Mubarak skal have en personlig formue, [hvordan han end har skrabet den sammen], på over 50 milliarder dollar...

'Muburak is said to have a personal fortune, [regardless how he might have scraped it together], of more than 50 billion dollars...'

Non-focusable om-clauses are also non-nuclear, and express a fairly similar meaning to that of the $h v$-clauses, i.e. the inevitability of the superordinate proposition despite obstacles. Like the $h v$-clauses they may also feature specific 


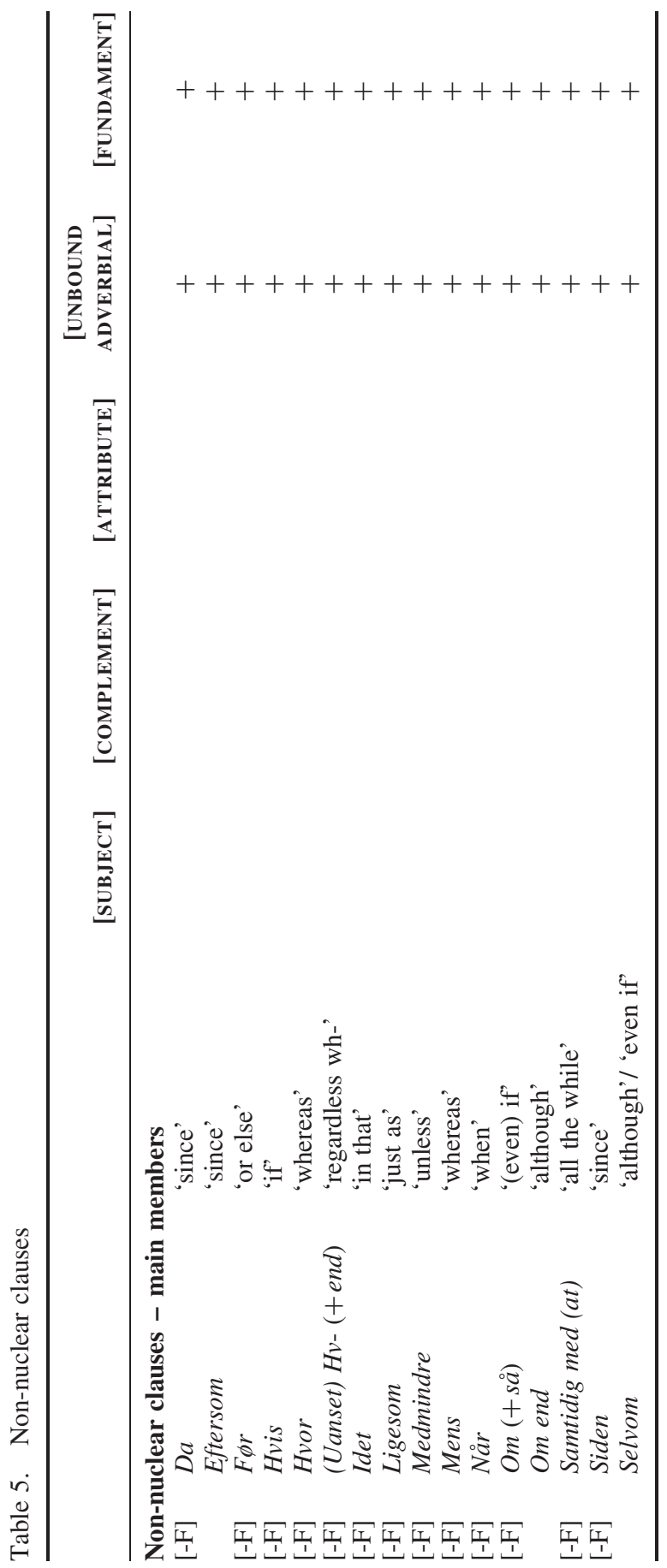




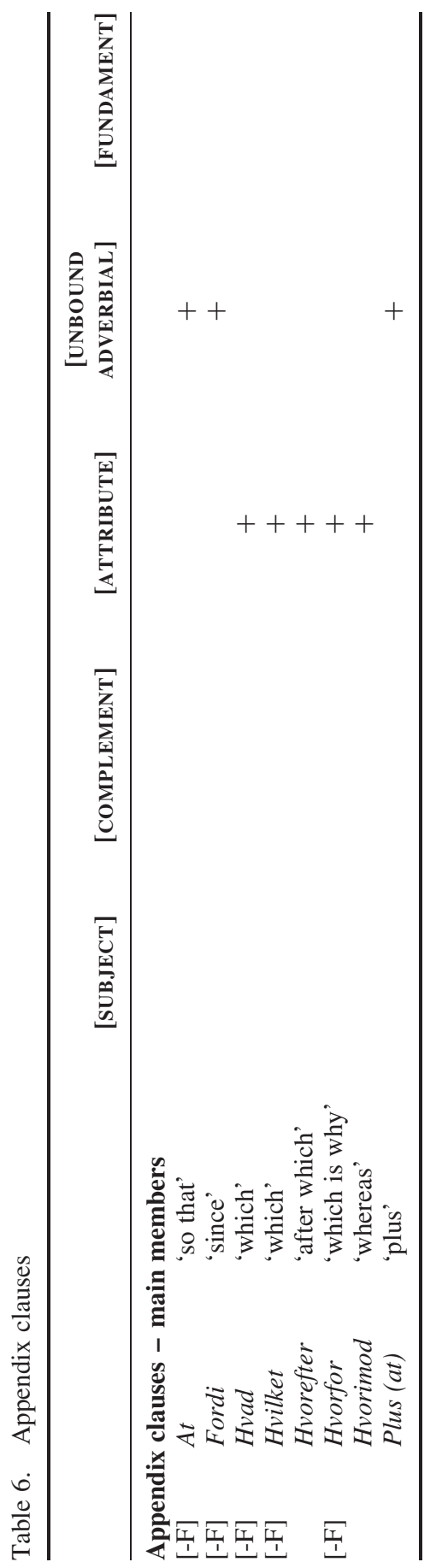


elements to help disambiguate the clause, for example the adverbials så or end, or initial modifiers such as uanset, ligegyldig, lige meget, etc.:

(90) (BySoc)

nå men altså fodbold det spiller jeg endnu ik' det tror jeg aldrig jeg slutter med [om jeg så bliver halvfems der]

'well but anyway football I still play right I think I'll never stop that [regardless if I then turn ninety there] '

Moreover, non-focusable hvor-clauses without the above-mentioned special elements may express an adversative relation:

(91) (Korpus DK)

[Hvor alvoren ligefrem svøber sig om Hamburger], lignede Meinert $i$ går en stor, glad dreng, der havde fäet alt det, han havde фnsket sig i julegave

'[While the gravity no less than wraps itself around Hamburger], yesterday

Meinert looked like a big, happy boy who had got all he wanted for Christmas'

(92) (BySoc)

altså vi kan da sidde og grine og have det sjovt ik' [hvor den anden han er sådan gået meget ned med han £ altså han er gået ned på grund af $\sim$ druk $o g \sim$ sådan noget] ik'

'you know we're able to sit and laugh and have fun right [while the other one he's you know fallen down he £ you know he's fallen into $\sim$ drinking and $\sim$ stuff like that] right'

Finally, non-focusable hvis-clauses are, as discussed, non-nuclear. They designate various kinds of illocutionary modification of the superordinate clause content. Their meanings are related to or derived from the objective conditional meaning of the semi-nuclear variant.

\section{Appendix clauses}

\subsection{Definition and main members}

Appendix clauses are distinguished by their inability to occur in the [FUNDAMENT] position of the superordinate clause. Their syntactic functions are varied and not always clearly determined, as illustrated in Table 6 below, emphasizing the fact that they are classified based on topological criteria alone. Like non-nuclear clauses, they are generally non-focusable, as indicated by [-F] for each polysemous type.

\subsection{General characteristics}

Appendix clauses are not defined syntactically but topologically - they share the distributional property of occurring usually at the end of sentences, and never initially: 
(93) (www.skakshoppen.dk)

DGT Easy skak ur er velegnet til skoleskakklubben, [hvorimod vi anbefaler at bruge DGT 2010 til skakklubben eller til hjemmet]

'DGT Easy chess clock is suitable for the school's chess club, [whereas we recommend DGT 2010 for the chess club or your home]'

(93') *[Hvorimod vi anbefaler at bruge DGT 2010 til skakklubben eller til hjemmet], er DGT Easy skak ur velegnet til skoleskakklubben

'[whereas we recommend DGT 2010 for the chess club or your home],

DGT Easy chess clock is suitable for the school's chess club'

Appendix clauses overlap to a great extent with what Hansen and Heltoft treat as "connective" subclauses, i.e. semantically coordinate, largely independent subclauses with near-speech act properties (Hansen and Heltoft 2011: 1554). Some appendix clauses are best described as [UNBOUND ADVERBIAL], although they are not topologically mobile, and others are traditionally characterized as relative-like clauses resembling [ATTRIBUTES], modifying for example the entire superordinate clause:

(94) (BySoc)

men min mor og far de \# de s- eller min mor $\sim$ forlangte at jeg betalte for at bo hjemme [hvilket jeg var lidt sur over dengang]

'but my mom and dad they \# they s- $\sim$ or my mom $\sim$ wanted me to pay for living at home [which I was a bit annoyed about at the time]'

(94') *[hvilket jeg var lidt sur over dengang], forlangte min mor at jeg betalte for at bo hjemme

'[which I was a bit annoyed about at the time], my mother demanded me to pay for living at home'

(95) (BySoc)

men det er klart det aendrer sig jo af £ jo aeldre man bliver ik' og £og man ikke $\sim$ ligesom $\sim £$ er i de der grupper mere og $£$ [plus at man også er $£$ er under uddannelse og sådan noget altså]

'but certainly it does change when $£$ the older you get right and $£$ and you're not $\sim$ like $\sim £$ in these groups any longer and $£$ [plus that you also are $£$ are under education and stuff like that you know]'

(95') *[plus at man også er under uddannelse], cendrer det sig jo af £ jo aeldre man bliver og man ikke ligesom er $i$ de der grupper mere

'[plus that you also are $£$ are under education and stuff like that you know], certainly it does change when $£$ the older you get and you not like are in these groups any longer' 


\subsection{Cases of polysemy}

Where the [ATTRIBUTE] group is concerned, some $h v$-clauses, for example hvorfor-, hvad- and hvilket-clauses, have both nuclear and appendix variants, as discussed in the treatment of nuclear clauses, depending on their focusability features. In the [UNBOUND ADVERBIAL] group, the appendix at-clause is to be distinguished from the nuclear at-/Ø-clause. Also, as discussed in the seminuclear section, fordi-clauses can be either semi-nuclear clauses or appendix clauses explaining/justifying the superordinate clause speech act. As most of these polysemous cases have thus already been discussed, the essence of appendix clauses is now accounted for. However, there are certain additional empirical features relevant to this class, influencing other parts of the classification framework as well, which I discuss in the final sections to follow.

\section{Discussion and conclusion}

\subsection{Are V2 subclauses appendix clauses?}

Danish subclauses can be said to alternate between (at least) two internal topological configurations, one based on V3 word order and one based on V2 word order - that is, one in which the finite verb occurs in the third position of the subclause, for example after any adverbial, and one in which it occurs in the second position, before any adverbial (note the verb positions relative to the boldfaced adverbials):

(96) (www.psykeogsex.dk)

Du har ganske ret $i$, at jeg stadig er vred på ham

V3 word order

'You are quite right [that I still am angry at him]'

(97) (http://mathildemunkholm.blogspot.com/)

Ellers skal det ikke vare en hemmelighed, [at jeg er

stadig meget alene i Paris]

V2 word order

'Apart from that it's no secret [that I am still very much

alone in Paris]'

Although the word order configuration of a subclause is part of its material, I have not incorporated the V3/V2 distinction in the classification criteria laid out so far. One reason is the fact that only subclauses featuring an adverbial such as stadig ('still'), or for example a fronted object, are in fact marked for one of the configurations, which would restrict the empirical basis of the classification in an unwanted way. Another reason is that it is a somewhat disputed issue whether or to what extent the distinction is semantically, socially and/or regionally motivated, and consequently on what basis certain kinds of subclauses may be said to actually have the V2 ability or not (V3 or 'unmarked' being the traditional, normative 'default' word order of Danish subclauses) (see for example T.J. Jensen 2011). 
However, the V2 subclauses that are in fact found in modern standard Danish $^{11}$ share (at least) one distributional property that needs to be accounted for, i.e. the fact that they do not occur in the [FUNDAMENT] position. Rather, they tend to occur in the final position as in (97) above. This challenges my criteria for especially nuclear clauses, since they are distinguished by their ability to occur as [SUBJECTS], i.e. subject clauses in the canonical position, which is the fundament position. As shown by for example T.J. Jensen (2011), a large proportion of at-/Ø-clauses are in fact configured with V2 word order, which means these cannot be said to actually meet the defining criterion for nuclear clauses.

One way of handling this anomaly might be to stress that my classification criteria are based on distributional potentials rather than for example frequencies, and that the at-/Ø-clause type as such has the potential to occur as [SUBJECT] regardless of the fact that the internal word order choice seems to correlate systematically with ability or inability to actually realize this potential.

Another possible solution is to embrace the word order difference and incorporate it into the classification framework based on the observed fact that V2 subclauses never occur in the [FUNDAMENT] position (still with the general reservation made in notes 3 and 11). From this perspective, V2 subclauses can be said to share the distributional properties of appendix clauses, giving rise to the criterion that V2 word order, regardless of the clause type/variant in question, is itself a sufficient condition for classifying the clause as an appendix clause.

While the V2 criterion thus appears to basically outrank all the other classification criteria laid out, in reality this mainly affects the classification of at/Ø-clauses, since most other subclause types - apart from notably fordi- and plus (at)-clauses - are not very commonly constructed with V2 word order in modern standard Danish. Note that I consider the [FUNDAMENT] ability to be the only distributional property affected by the word order choice, meaning that for example at-/Ø-clauses with V2 word order still share the distributional properties of nuclear clauses in all other respects.

A motivation for including the V2 criterion is that it highlights an important semantic relation between V2 subclauses and (other) appendix clauses, in that V2 word order is typically tied to content properties such as "informativity", "assertiveness" and/or status as "main point of utterance", as discussed in for example Wiklund et al. (2009), Christensen and Heltoft (2010), Hansen and Heltoft (2011), and T.J. Jensen (2011) - a point illustrated in (98):

(98) (BySoc)

$n u \sim$ var man også så lille [at man oplevede det jo £ på en helt

anden måde] ik'

'now $\sim$ you were so little [that you did experience it $£$ in a completely different way] right'

\footnotetext{
${ }^{11}$ As mentioned in note 3, I do not claim to account for certain regional variants of Danish - a reservation of particular importance in the context of V3 vs. V2 subclause comparisons.
} 
This is a "degree-indicating" construction featuring an at-/Ø-clause with V2 word order. Due to the V2 structure, the actual degree indication remains in the background, while the subclause content is asserted and may be regarded the main point of the utterance. Without the V 2 criterion, the clause would classify as a nuclear clause, neglecting the fact that it could not appear (though adjoined with the remaining adjective phrase) in the [FUNDAMENT]:

(98’) *så lille [at man oplevede det jo på en helt anden måde], var man nu 'so little [that you did experience it in a completely different way] were you now'

Indeed, the inability of V2 subclauses to appear in the [FUNDAMENT] can be regarded a consequence of their assertiveness, informativity and/or status as main point of utterance - semantic properties that are incompatible with the general "backgrounding" tendency featured by the initial position (cf. for example Verstraete 2007). Another V2 example is warranted, in this case with a selvomclause:

(99) (BySoc)

det må jeg indrømme $£$ jeg $d$ - $£ n$-har ikke- $£$ jeg har ikke overskuddet til det?

[selvom jeg har faktisk overvejet $\sim £$ og blive skolelarer ik']

'I must admit $£$ I d- $£$ n- haven't got- $£$ I haven't got the energy for it ?

[although I have in fact thought $\sim £$ about becoming a school teacher right]'

The V2 structure enforces the independent assertiveness of the subclause, which is illustrated by the fact that the positive tag question $i k$ ' ('right') obtains its polarity from the subclause itself, not the (negative) superordinate clause, thus assigning the subclause more or less its own speech act status (for similar analyses of, for example, tag questions as "primary" vs. "secondary" status indicators, see Boye and Harder 2007). Treating V2 subclauses as appendix clauses in other words acknowledges important aspects of both their expression and content side.

\subsection{Are all "heavy" subclauses appendix clauses?}

However, similar distributional properties and content features may also be associated with a more general phenomenon than that of V2 word order, as illustrated by the non-V2 subclause in (100):

(100) (BySoc)

og så min far han havde varet så smart [at han havde varet ude at kфbe sådan en du ved sådan en rulle £ sådan en gammeldags en med sådan to ruller på ik' hvor man så kunne stikke tøjet ind igennem]

'and then my dad he had been so smart [that he had gone and purchased one of these you know one of these rollers $£$ one of these old-fashioned ones with two rollers on it right where you could then put your clothes through it]' 
While the subclause in (100) does not feature V2 word order (it is unmarked for word order), its very denseness seems to render it the main point of the utterance, and the idea of moving it to the [FUNDAMENT] position seems somewhat absurd:

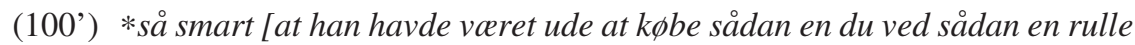
$£$ sådan en gammeldags en med sådan to ruller på ik' hvor man så kunne stikke tøjet ind igennem] havde min far varet

'so smart [that he had gone and purchased one of these you know one of these rollers $£$ one of these old-fashioned ones with two rollers on it right where you could then put your clothes through it] had my dad been'

Hence, this subclause can in fact also be said to meet the appendix clause criteria, suggesting that factors other than V2 word order may come into play in certain contexts, including for instance end-weight restrictions, as discussed in for example Quirk et al. (1985: 1039).

Accounting for clauses of this kind might call for yet another criterion, i.e. one concerning "heavy" subclauses. Yet, such end-weight restrictions are hardly structurally determined phenomena, and I would rather see this as an example of the general limitations of distributional analysis: linguistic structures are not strict, uninterpreted algorithms, but reflections of usage patterns and the contexts that motivate them. The subclause classification proposed here is, at best, a tool for exploring and understanding some of these reflections.

\subsection{Overview and final remarks}

The five subclause classes and their distributional properties are summarised in Table 7.

With the proposed classification at material level, Danish subclauses may be cross-classified in terms of material and function. The benefit of incorporating both levels of analysis instead of just the level of function, as seen in traditional grammar, may be highlighted by returning to the Hansen and Heltoft quote presented in section 2.2. Roughly, they argue that Danish nominal clauses are introduced by $a t$-, om- or $h v$-words, adverbial clauses are introduced by for example hvis, fordi, mens, selvom, etc., and attributive clauses are introduced by for example som, or $h v$-words, yet with the reservation that this is not always the case (Hansen and Heltoft 2011: 1480).

In fact, the clause types they mention correspond quite clearly to what I propose as (a) nuclear clauses, (b) semi-/non-nuclear clauses, and (c) attributional clauses, i.e. our results are indeed compatible. However, as opposed to the classification proposed here, the traditional one does not take the alternative functions of each subclause type properly into account, just as the absence of well-defined categories at material level, as opposed to mere lists of conjunctions, arguably blurs the functional purpose of the classification.

Moreover, employing a distributional approach to the classification is fruitful in several ways. For instance, it reveals structural distinctions within the 


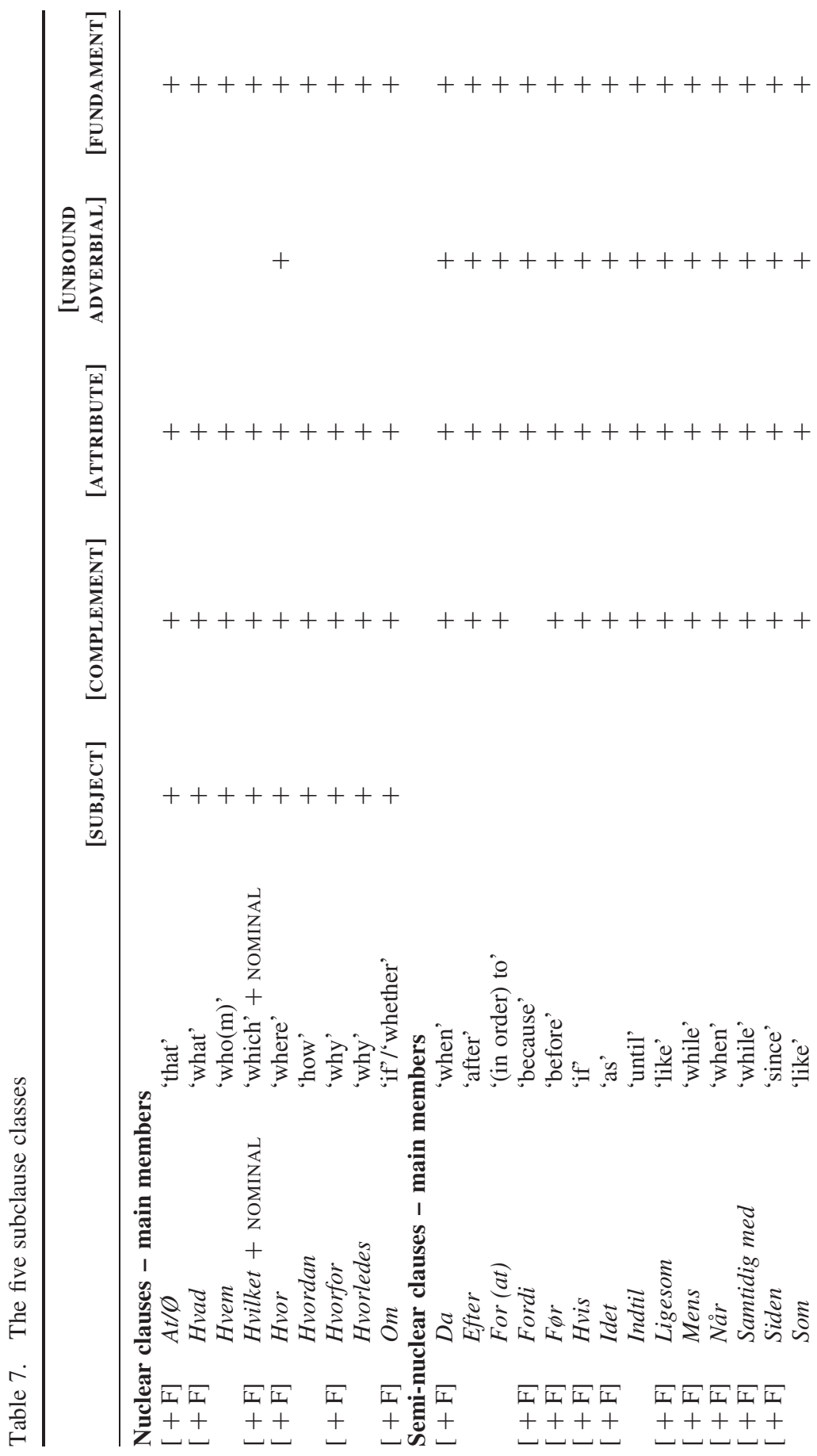




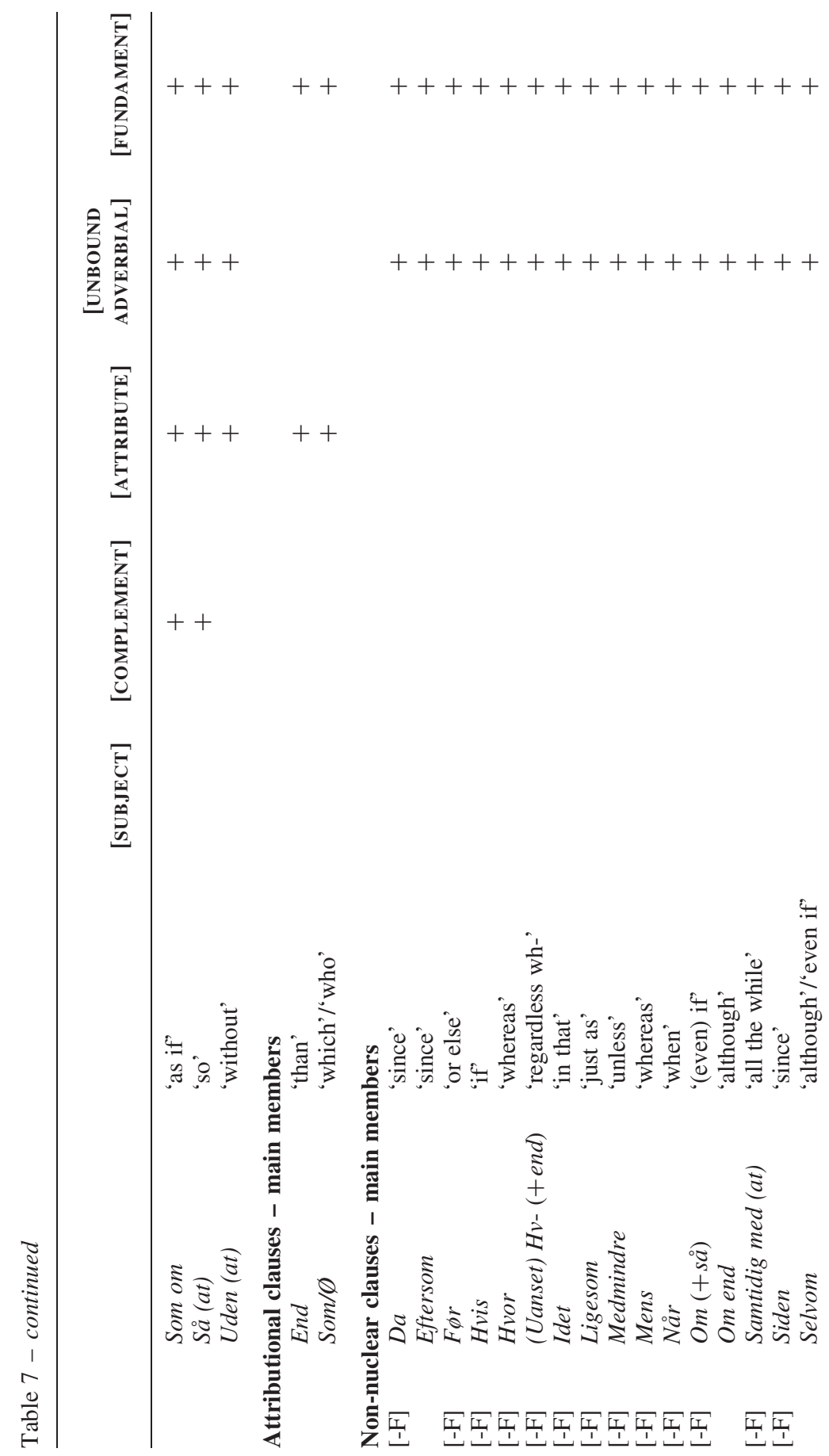




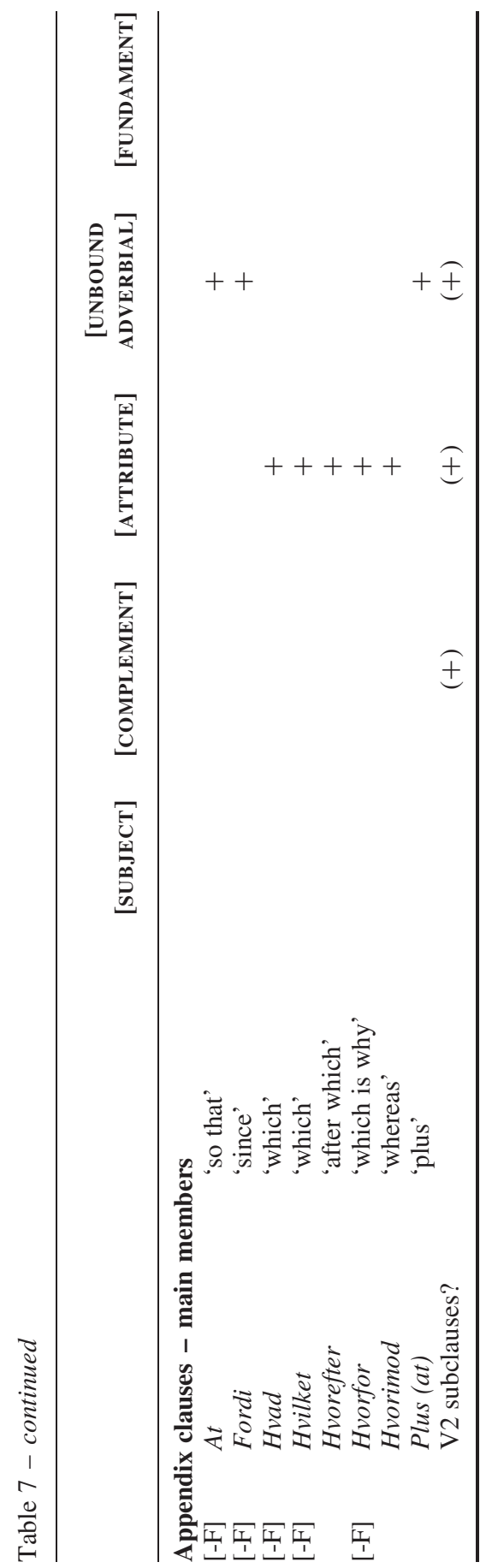


major bulk of subclauses that are typically treated together as adverbial clauses, as these are shown to be realized either by semi-nuclear clauses, non-nuclear clauses or certain appendix clauses. In addition, this approach to classifying subclauses yields more than just convenient divisions within a large linguistic domain; it specifies what each clause type/variant may actually be used for in context, and reveals how the classes are organized into a partial implicational hierarchy of "integratability" into the superordinate clause (note that the word "integratability" and not "integration" is used, focusing on the potential rather than the realization). Not least, the distributional approach gives access to clear falsification parameters, concerning both the classification criteria as such, and the individual clause types and variants ascribed to each class.

Finally, the "integratability" hierarchy reflects general semantic differences between the subclause classes that have been loosely accounted for in terms of the nature of the semantic relations the subclauses establish to their superordinate clauses, including semantic clause layering. Roughly, nuclear clauses express content that is stated, thought, asked about, contested, evaluated, etc. in the superordinate clause. Semi-nuclear clauses specify the objective circumstances such as time, place, manner, cause, condition, and so on - of what is expressed in the superordinate clause, whereas non-nuclear clauses express subjective circumstances, such as reason, reservation, opposition, explanation, etc. Attributional clauses establish more or less abstract relations of comparison between (parts of) the superordinate clause and the subclause content, and finally appendix clauses, relating to the highest layers of the semantic hierarchy, comment on the superordinate clause content or simply assert more or less independent statements. The fact that appendix clauses are defined in negative terms, simply as the only subclauses which cannot occur in the [FUNDAMENT] position (including all V2 subclauses), should not be taken to imply that the appendix class is merely a residual category. Rather, it highlights the central role of the fundament position in Danish sentence structuring. Thus, [FUNDAMENT] ability, and the corresponding non-assertion/secondary-point-of-utterance ability, may be regarded a prototypical feature of Danish subclauses from a structural perspective, while in actual speech appendix clauses with their assertiveness and near-main clause features may be as frequent or even outnumber the remaining classes.

\section{Acknowledgements}

This work has been financially supported by Niels Bohr Fondet/Mag. Art. Marcus Lorentzens legat, Cand.mag. Karen Iversens Legat and Professor, Dr.phil. Viggo Brøndals og Hustrus Legat, for which I would like to express my gratitude. In addition, I wish to thank Dr. Jean-Christophe Verstraete and the Linguistics Department at Katholieke Universiteit Leuven, as well as Torben Juel Jensen, Peter Harder, Kasper Boye, Janus Mortensen and two anonymous reviewers for insightful comments on previous versions of this paper. 


\section{References}

Andersson, L.-G. 1975. Form and Function of Subordinate Clauses. Göteborg: University of Göteborg, Department of Linguistics.

Becker-Christensen, C. 2010. Dansk syntaks. Frederiksberg: Samfundslitteratur.

Boye, K., and P. Harder. 2007. Complement-taking predicates: Usage and linguistic structure. Studies in Language 31, no. 3: 569-606.

Butler, C.S. 2003. Structure and Function: A guide to Three Major Structural-Functional Theories 1-2. Amsterdam: John Benjamins.

Christensen, T.K., and L. Heltoft. 2010. Mood in Danish. In Mood in the Languages of Europe, ed. B. Rothstein and R. Thieroff, 85-102. Amsterdam: John Benjamins.

Cristofaro, S. 2003. Subordination. Oxford: Oxford University Press.

Diderichsen, P. 1946. Elementar dansk grammatik. Copenhagen: Nordisk Forlag.

Diderichsen, P. 1957. Elementcer dansk grammatik. 2. ed. Copenhagen: Gyldendal, (Orig. pub. 1946.).

Diderichsen, P. 1958. The importance of distribution versus other criteria in linguistic analysis. In Proceedings of the 8th International Congress of Linguistics, 156-82. Oslo: Oslo University Press.

Dik, S.C. 1997a. The Theory of Functional Grammar. Part 1: The Structure of the Clause, ed. K. Hengeveld. Berlin: Mouton de Gruyter.

Dik, S.C. 1997b. The Theory of Functional Grammar. Part 2: Derived and Complex Structures, ed. K. Hengeveld. Berlin: Mouton de Gruyter.

Dik, S.C., K. Hengeveld, E. Vester and C. Vet. 1990. The hierarchical structure of the clause and the typology of adverbial satellites. In Layers and Levels of Representation in Language Theory: A Functional View, ed. A.M. Bolkestein, J. Nuyts and C. Vet, 25-70. Amsterdam: John Benjamins.

Engberg-Pedersen, E., M.D. Fortescue, P. Harder, L. Heltoft and L.F. Jakobsen, ed. 1996. Content, Expression and Structure: Studies in Danish Functional Grammar. Amsterdam: John Benjamins.

Engberg-Pedersen, E., M.D. Fortescue, P. Harder, L. Heltoft and L.F. Jakobsen, eds. 2005. Dansk funktionel lingvistik: En helhedsforståelse af forholdet mellem sprogstruktur, sprogbrug og kognition. Copenhagen/Roskilde: University of Copenhagen/Copenhagen Business School/Roskilde University.

Faarlund, J.T., S. Lie and K.I. Vannebo. 1997. Norsk referansegrammatikk. Oslo: Universitetsforlaget.

Givón, T. 1984. Syntax: A Functional-Typological Introduction. 2 vols. Amsterdam: John Benjamins.

Haegemann, L. 2006. Argument fronting in English, Romance CLLD, and the left periphery. In Cross-linguistic Research in Syntax and Semantics: Negation, Tense and Clausal Architecture, ed. R. Zanuttini, H. Campos, E. Herburger and P. Portner, 27-52. Georgetown: Georgetown University Press.

Halliday, M.A.K. 1994. An Introduction to Functional Grammar. 2nd ed. London: Edward Arnold.

Hansen, A. 1967. Moderne dansk 1. Copenhagen: Det Danske Sprog- og Litteraturselskab/Grafisk Forlag.

Hansen, E. 1977. Damonernes port. Copenhagen: Hans Reitzel.

Hansen, E. 1998. Kriterier for inddeling af ledsætninger. In Ny forskning i grammatik 5: Sophienbergsymposiet, ed. P. Colliander and I. Korzen, 7-22. Odense: Odense Universitetsforlag.

Hansen, E., and L. Heltoft. 2011. Grammatik over det danske sprog. Copenhagen/Odense: Det Danske Sprog- og Litteraturselskab/Syddansk Universitetsforlag.

Harder, P. 1996a. Linguistic structure in a functional grammar. In Content, Expression and Structure: Studies in Danish Functional Grammar, ed. E. Engberg-Pedersen, 
M.D. Fortescue, P. Harder, L. Heltoft and L.F. Jakobsen. Amsterdam: John Benjamins.

Harder, P. 1996b. Subordinators in a semantic clause structure. In Complex Structures: A Functionalist Perspective, ed. B. Devriendt, L. Goossens and J. Van Der Auwera, 93-118. Berlin: Mouton de Gruyter.

Heltoft, L. 1990. En plads til sprogvidenskabens hittebørn: Om talesprog og sætningsskema. In Selskab for Nordisk Filologi - årsberetning 1987-1989, 26-45. Copenhagen: Selskab for Nordisk Filologi.

Hengeveld, K. 1996. The internal structure of adverbial clauses. In Complex Structures: A Functionalist Perspective, ed. B. Devriendt, L. Goossens and J. Van Der Auwera, 119-48. Berlin: Mouton de Gruyter.

Hengeveld, K. 1998. Adverbial clauses in the languages of Europe. In Adverbial Constructions in the Languages of Europe, ed. J. Van Der Auwera and D.P. Ó Baoill, 335-419. Berlin: Mouton de Gruyter.

Hengeveld, K., and J.L. Mackenzie. 2008. Functional Discourse Grammar. Oxford: Oxford University Press.

Huddleston, R., and G.K. Pullum. 2002. The Cambridge Grammar of the English Language. Cambridge: Cambridge University Press.

Huddleston, R., and G.K. Pullum. 2004. The classification of finite subordinate clauses. In An International Master of Syntax and Semantics: Papers Presented to Aimo Seppänen on the Occasion of his 75th birthday, ed. G. Berg, J. Herriman and M. Mobärg, 103-16. Gothenburg: Acta Universitatis Gothoburgensis.

Jakobsen, L.F. 1996. Beskrivelsesniveauer og dimensioner i den grammatiske model. Hermes - Journal of Language and Communication Studies 17: 139-68.

Jendraschek, G. 2007. Subordinate, embedded, and dependent clauses: A terminological confusion that Iatmul can help disentangle. Handout for public lecture given on 17 July 2007, http://uni-regensburg.academia.edu/GerdJendraschek/Papers.

Jensen, A. 2003. Clause linkage in spoken Danish. PhD thesis, University of Copenhagen.

Jensen, T.J. 2011. Ordstilling i ledsætninger i moderne dansk talesprog. In Ny forskning $i$ grammatik 18, ed. P. Durst-Andersen and H.H. Müller, 124-50. Odense: Odense Universitetsforlag.

Jespersen, O. 1927. A Modern English Grammar on Historical Principles, Part II. Heidelberg: Carl Winters Universitätsbuchhandlung.

Jespersen, O. 1939-40. Ledsætningernes (bisætningernes) systematik. Acta Philologica Scandinavica 14: 65-74.

Laury, R., and R. Suzuki. 2011. Subordination in Conversation. Amsterdam: John Benjamins.

Lehmann, C. 1988. Towards a typology of clause linkage. In Clause Combining in Grammar and Discourse, ed. J. Haiman and S.A. Thompson, 281-326. Amsterdam: John Benjamins.

Matthews, P.H. 2007. The Concise Oxford Dictionary of Linguistics (Online). Oxford: Oxford University Press, Oxford Reference Online. http://www.oxfordreference.com/ views/ENTRY.html?subview=Main\&entry=t36.e951.

Mikkelsen, K. 1911. Dansk ordföjningslare med sproghistoriske tillag: Håndbog for viderekomne og larere. Copenhagen: Hans Reitzels Forlag.

Mortensen, S.S. 2006. Temporale konjunktioner i dansk. MA thesis, Roskilde University.

Mortensen, S.S. 2011. Problemer og udveje i dansk ledsætningsklassifikation. In Ny forskning i grammatik 18, ed. P. Durst-Andersen and H.H. Müller, 225-47. Odense: Syddansk Universitetsforlag.

Pedersen, K.M. 2009. Indre at i danske dialekter. In Dramatikken i grammatikken, ed. R. Therkelsen and E.S. Jensen, 321-33. Roskilde: Roskilde University/Institut for Kultur og Identitet. 
Quirk, R., S. Greenbaum, G. Leech and J. Svartvik. 1985. A Comprehensive Grammar of the English Language. London: Longman.

Smessaert, H., B. Cornillie, D. Divjak and K. van den Eynde. 2005. Degrees of clause integration: From endotactic to exotactic subordination in Dutch. Linguistics 43, no. 3: 471-521.

Smolka, V. 2005. Non-extraposed subject clauses. In Theory and Practice in English Studies 3: Proceedings from the Eighth Conference of British. American and Canadian Studies, 137-43. Brno: Masarykova Univerzita.

Teleman, U., S. Hellberg and E. Andersson. 1999. Svenska Akademiens grammatik 4: Satser och meningar. Stockholm: Svenska Akademien.

Therkelsen, R. 2003. The functions of Danish causal conjunctions. In Proceedings of the 19th Scandinavian conference of linguistics, ed. A. Dahl, K. Bentzen and P. Svenonius, 446-56. Tromsø: University of Troms $\varnothing$.

Togeby, O. 2003. Fungerer denne satning? Funktionel dansk sproglaere. Copenhagen: Gads Forlag.

Van Valin, R.D., Jr. and R.J. La Polla. 1997. Syntax - Structure, Meaning and Function. Cambridge New York: Cambridge University Press.

Verstraete, J.-C. 1999. The distinction between epistemic and speech act conjunction. Belgian Essays on Language and Literature 1999: 119-30.

Verstraete, J.-C. 2005. Two types of coordination in clause combining. Lingua 115, no. 4: 611-26.

Verstraete, J.-C. 2007. Rethinking the Coordinate-Subordinate Dichotomy: Interpersonal Grammar and the Analysis of Adverbial Clauses in English. Berlin: Mouton de Gruyter.

Wiklund, A.-L., K. Bentzen, G.H. Hrafnbjargarson and o. Hróarsdóttir. 2009. On the distribution and illocution of V2 in Scandinavian that-clauses. Lingua 119, no. 12: 1914-38.

Wiwel, H.G. 1901. Synspunkter for dansk sproglaere. Copenhagen: Det Nordiske Forlag. 